\title{
COMPANHIA DE SANEAMENTO DO PARÁ (COSANPA)
}

\section{PARECER}

EMENTA: Serviço público de abastecimento de água e de esgotamento sanitário. Regiōes metropolitanas, funções públicas de interesse comum e competência para a prestação de serviços públicos. Imposição constitucional do princípio da equalização tarifária. Os regimes constitucionais de prestação de serviços públicos e a autonomia federativa. Cooperação voluntária e necessária entre entidades políticas. Inaplicabilidade à hipótese da Lei Federal no 8.987, de 13 de fevereiro de 1995.

"Governo e cooperação são, em tudo, as leis do progresso; anarquia e antagonismo, as leis do retrocesso". JOHN RUSKIN

\section{A CONSULTA}

\section{A COMPANHIA DE SANEAMENTO DO} PARÁ - COSANPA, sociedade de economia mista do Estado do Pará, cuja constituição foi autorizada pela Lei Estadual $n^{\circ} 4.336$, de 21 de dezembro de 1970, delegatária de serviços públicos de abastecimento de água e de esgotos sanitários na Capital do Estado e nos Municípios que conformam sua Regiāo Metropolitana, expõe e indaga o que se segue.

A CONSULENTE, presta serviços públicos de abastecimento de água e de esgotamento sanitário a vários Municípios do Estado do Pará, inclusive à Cidade de Belém e aos demais centros conurbanos que conformam sua Região Metropolitana, desde o $2^{2}$ Império, sucedendo, nesse serviço público, a Compa- nhia de Águas do Gram-Pará (1881-1895), a Inspetoria de Águas de Belém (1895-1899), a Diretoria dos Trabalhos Públicos (18991901), a Diretoria do Serviço de Água (19011940), o Serviço de Águas (1940-1946), o Departamento Estadual de Águas (19461962) e o Departamento de Águas e Esgotos (1962-1970).

São, portanto, serviços públicos de saneamento planejados e executados há mais de um século nesses centros urbanos, primeiramente, a cargo da Província, e, posteriormente, do Estado, no curso de todos os regimes constitucionais porque passou este País.

Entretanto, há três meses (em setembro de 1999), alegando a condição de "Poder Concedente dos serviços de água e esgoto" e dizendo-se fundado no art. 30 da Lei Federal no 8.987, de 13 de fevereiro de 1995, o Município de Belém fez notificar extrajudicialmente a CONSULENTE para que providenciasse, em três dias, a entrega de inúmeros documentos e informações de toda natureza, não só os relativos aos serviços públicos que presta no referido Município, como dados pessoais dos usuários.

Mais recentemente (em novembro de 1999), sustentando a mesma alegação, de ser o "Poder Concedente" dos serviços de água e esgoto prestados pela CONSULENTE, o Município de Belém ajuizou ação cautelar de busca e apreensão cumulada com pedido cautelar sucessivo de exibição de documento, com pedido de "liminar 'initio litis"", para obter judicialmente documentos e informações, invocando, como fundamento legal, o art. $42, \S 22$, da Lei $n^{2} 8.987$, de 13 de fevereiro de 1995 . 
O que se nota, desde logo, é que o Município de Belém ingressou em juízo sem sequer demonstrar sua própria convicção e certeza com relação à natureza da pretextada relaçāo jurídica com a CONSULENTE, uma vez que, logo no item $I$ de sua inicial, começa por afirmar a existência de uma exploração de serviço público "sem contrato", portanto nāo-concessional, para, logo a seguir, nos itens 2 e 3, dar conta de tratativas visando à "prorrogação da concessão" $\mathrm{e}$, ainda, da existência de um Parecer da Consultoria Geral do Estado confirmando a existência de uma relação contratual precária, para voltar a afirmá-la no item 4.

O simples desdizer-se ao peticionar em juízo, já é suficientemente revelador do completo desconhecimento evidenciado pelo Municipio de Belém sobre a natureza jurídica da prestação de serviço público realmente existente, e das relações a ele atinentes, o que, em parte, explica os muitos equívocos em que laborou, conforme se irá expor neste Parecer.

Mas, mesmo sem aprofundar sobre as contradições e deficiências técnicas outras, que comprometem a coerência dos dois petitórios daquela Municipalidade, evidencia-se que o correto enfoque jurídico dever-se-á concentrar sobre duas questōes centrais que se imbricam: a titularidade do Poder Concedente para a prestação desses serviços públicos me. tropolitanos de água e esgoto, de que faz parte aquele Município, e a legitimidade da atuação da CONSULENTE, como delegatária estadual desses serviços.

Diante do exposto e das considerações preliminares expendidas sobre a questão, a CONSULENTE desenvolve e propōe os seguintes QUESITOS:

\section{QUESITO}

"Sob o prisma da Constituição e da legislação infraconstitucional aplicável à matéria seria correto afirmar que os serviços públicos de abastecimento de água e coleta de esgotos prestados nos Municípios que compõem a Região Metropolitana de Belém (criada por força de Lei Complementar do Estado), predomina o interesse metropolitano em detrimento do interesse local?"

\section{QUESITO}

"A integração dos sistemas de abastecimento de água que servem aos municípios da Região Metropolitana de Belém, seria fator essencial para determinar a prevalência do interesse metropolitano em face do interesse local?"

\section{QUESITO}

"Predominando o interesse metropolitano, descaracterizado o interesse local, seria correto afirmar-se que a titularidade do Poder de Concessão seria do Estado (pessoa jurídica de direito público interno), mesmo existindo contrato de concessão firmado com alguns municípios da $R M B$, antes da promulgação da Constituição Federal de 1988, da Lei de Concessões, e da Lei Complementar que criou a RMB?"

\section{QUESITO}

"O fato de existir contrato de concessão com alguns municípios da RMB, firmados antes da promulgação da Constituição Federal de 1988, da Lei de Concessões e da Lei Complementar que criou a RMB, seria fato impeditivo capaz de invalidar a tese de que nas Regiōes Metropolitanas criadas regularmente por Lei Complementar, o Poder Concedente seria o Estado, por predominar, no caso, o interesse metropolitano?"

\section{QUESITO}

"Na remota hipótese de prevalecer a tese de que predominaria o interesse local em detrimento do interesse metropolitano na $R M B$, para os serviços de abastecimento de água $e$ coleta de esgotos na região prestados, seria correto afirmar que, nas concessões de fato, portanto a título precário, o prazo previsto no parágrafo 2o, do artigo 42 , da Lei $8.987 / 95$, - necessário à realização dos levantamentos e avaliações indispensáveis à organização das licitações que precederão a outorga das concessões que as substituirão, prazo esse que não poderá ser inferior a 24 (vinte e quatro) meses - conta-se a partir da iniciativa do poder Concedente para esse determinado fím ou da promulgação da referida Lei?" 
$6^{\circ}$ QUESITO

"Na eventualidade de configurar-se a hipótese do parágrafo 20 , do artigo 42 , da Lei $8.987 / 95$, qual o procedimento que deveria ser observado pelo Poder Concedente e quais as providências judiciais e extrajudiciais que a concessionária deveria adotar na defesa de seus interesses?"

\section{APRECIAÇÃO GERAL E MÉTODO EXPOSITIVO}

Orbita, toda a quesitação proposta, em torno da definição da titularidade da prestação do serviço público de abastecimento de água e de esgotamento sanitário no Município de Belém.

Posta nesses termos, a questão é de relativamente simples equacionamento:

De um lado, o Município de Belém se tem como a entidade titular dos serviços, invocando a direta aplicação do art. $30, \mathrm{~V}$, da Constituiçāo, que atribui competência aos Municípios para organizar e prestar, diretamente ou sob regime de concessão ou permissão, os serviços públicos de interesse local," 1 sendo induvidoso que o serviço público de abastecimento de água e esgoto assim o é.

De outro lado, a CONSULENTE se tem como delegatária legal do Estado do Pará (Lei Estadual n².336, de 21 de dezembro de 1970), que sempre foi e ainda o é, o legítimo titular desses serviços, executando-os, sem solução de continuidade, desde o $2^{2}$ Império. A sua legitimidade, que preexistia à Constituição de 1988, por não ter sido então deferida expressamente a titularidade aos Municípios, se manteve depois da entrada em vigor da Lei Complementar federal $n^{2} 14$, de 8 de junho de 1973, e teve continuidade, na vigência da atual ordem constitucional, com fundamento no art. $25, \S 32$, da Carta de 1988 , por ser, o Estado, há 26 anos, o titular dos serviços públicos de interesse comum da Região Metropolitana de Belém. A CONSULENTE, por sua vez, é a entidade paraestatal estadual delegatária e executora dos referidos serviços.

Não obstante, como visto, ser relativamente simples esse equacionamento da questão central, deve-se reconhecer que a extrema prolixidade da Carta de 1988, a que se acrescem a assistematicidade das dezenas de emendas suportadas no exíguo período de dez anos e as insuficiências técnicas da legislação infraconstitucional de execução, suscitam dificuldades que merecem ser examinadas mais detidamente, o que se faz, considerando analiticamente os seguintes aspectos:

1. a disciplina constitucional dos recursos hídricos e de seu gerenciamento;

2. o tratamento constitucional da água;

3. o serviço público de abastecimento de água e esgotamento sanitário;

4. a caracterização do interesse predominante como critério definidor da competência;

5. as regiões metropolitanas como instrumentos do interesse comum;

6. a importância principiológica constitucional da equalização de tarifas;

7. as regiōes metropolitanas a titularidade dos serviços públicos de saneamento;

8. os regimes de execução de serviços públicos;

9. a natureza do regime in casu e as distinçōes entre cooperação voluntária e necessária;

10. a aplicabilidade da Lei federal n 8.987, de 13 de fevereiro de 1995, sobre concessões e permissões de serviços públicos.

A partir do estudo dessas premissas serão apresentadas as conclusões em resposta aos quesitos.

\section{OS RECURSOS HÍDRICOS E SEU GERENCIAMENTO}

Além da escassez do líquido, fenômeno que já vem ocorrendo em muitas áreas do globo, a acelerada elevação dos custos necessários para desenvolver-se, adequada e racional- 
mente o ciclo de uso da água, que é, basicamente, o seu processo de captação, tratamento, adução e distribuição para consumo, tem levado a uma paulatina ampliação do seu equacionamento político e jurídico em todos os países do mundo, em busca de soluções que conciliem o seu, já polêmico, conceito de multiuso', com a garantia de generalidade, aperfeiçoamento e modicidade dos serviços públicos de água e esgoto a serem prestados a populações urbanas em crescimento e cada vez mais demandantes.

Com efeito, tal como já ocorreu neste século com vários outros serviços públicos, como os de eletricidade, os telefônicos, os de abastecimento de gás, os de transporte, e tantos outros mais, que se expandiram e se desenvolveram tecnologicamente muito além das limitadas dimensōes paroquiais com que timidamente se iniciaram, também esses, os prestados no ciclo de uso da água, já não mais prescindem de soluções amplas e de escala.

Exigem, por isso, um coerente tratamento juspolítico integrador e centralizador, que hoje se torna absolutamente necessário, para que possam ser devidamente garantidos, a existência e a eficácia dos referidos princípios regedores dos serviços públicos, a saber: a sua necessária eficiência, guindada a princípio constitucional (art 37, caput, CF), a generalidade, como forma de eliminar as desigualdades, obedecendo a um princípio fundamental da Constituição (art. 30, III), o permanente aperfeiçoamento, tanto em termos de extensão como de qualidade (art. 175, IV, CF), e, não menos importante, em termos econômicos, a modicidade (art 175, III, CF), para que o consumidor seja pouco onerado em troca de um serviço de boa qualidade.

Ora, a escala local, comunal e limitada, não se presta para oferecer suficiente garantia de que serão observadas tais características nesses tipos de serviços públicos, por serem tecnicamente complexos e demandantes de escala para que se viabilizem. Daí, o constituinte, atento ao problema crucial dessa imprescindível eficiência técnica e econômica, se ter valido de inúmeras normas concentradoras de competência na União, visando, com isso, reunir capacidade de planejamento e de execução para superar as restriçōes de Estados e Municípios de menores recursos econômicos e gerenciais.

Explicam-se, dessa maneira, as numerosas opções constitucionais concentradoras, como as que se revelam na outorga de competências administrativas da União para o serviço postal e o correio aéreo (art. 21, X), para as telecomunicações (art. $21, \mathrm{XI}$ ), para a radiodifusão sonora e de sons e imagens (art. 21, XII, a), para a energia elétrica e aproveitamento energético dos cursos de água (art. 21,XII, b), para a navegaçāo aérea e a infra-estrutura aeroportuária (art. 21, XII, c), para os transportes ferroviário e aquaviário entre portos brasileiros, e fronteiras nacionais, que transponham os limites de Estado ou Território (art. 21, XII, d), para os serviços de transporte rodoviário interestadual e internacional de passageiros (art. 21, XII, e) e para os servicos portuários (art. $21, \mathrm{XI}, f$ ), bem como para estabelecer diretrizes para o gerenciamento de recursos hídricos e para definir critérios de outorga de direitos de seu uso (art. 21, XIX), diretrizes para o desenvolvimento urbano, inclusive habitação, saneamento básico e transportes urbanos (art. $21, \mathrm{XX}$ ) e principios e diretrizes para o sistema nacional de viação ( art. 21, XXI).

Além de todas essas opções específicas pela centralização, a Constituição valeu-se, ainda, mais três vezes, do mesmo princípio da concentração de competência em serviços públicos de escala, desta feita nos Estados-membros, ainda especificamente, para os serviços locais de gás canalizado (art. $25, \S 2^{2}$ ), genericamente, para atribuir ao Estado o desempenho de qualquer outro serviço público, sempre que uma competência específica não tenha sido atribuída à União nem se contenha

1 O multiuso da água se caracteriza por sua essencialidade à vida humana, aos animais, aos vegetais, à higiene, à geração hidrelétrica, ao transporte fluvial e à manutenção do equilibrio micro-climático, além de outros usos lúdicos e esportivos. 
no mero interesse local (em virtude dos poderes remanescentes do art. $\left.25, \S 1^{2}\right)$ e, ainda uma vez mais, esta, de forma específica $e$ destacada, atribuindo poderes aos Estados para, mediante lei complementar, integrar a organização, o planejamento e a execução de funções públicas de interesse comum (art. 25, \$3Q).

Como se pode observar, no exercício dos poderes constitucionais atribuídos nesse dispositivo, voltado ao enfrentamento de problemas de escala nos serviços públicos, típicos de regiōes densamente urbanizadas, que abrangem as circunscrições de mais de um município, os Estados-membros podem concentrar administrativamente serviços públicos regionais, que devam ser prestados homogeneamente a mais de uma unidade municipal.

Aqui se situam, precisamente, entre outros serviços a serem integrados, os de água $e$ esgoto, bastando ao Estado, não mais que definir politicamente o interesse comum, o que deverá perfazer através de Lei Complementar instituidora de órgãos especiais de gestão específicos, que tanto podem ser regiões metropolitanas, como aglomeraçōes urbanas ou microrregiões, conforme a hipótese geo-político-econômica de que se trate e em que ocorram interesses comuns que transcendam os locais.

Nenhuma outra esfera política, órgão ou Poder pode intervir no exercício dessa competência constitucional dos Estados-membros, desempenhada exclusivamente através de um devido processo legislativo estadual, insujeitado a quaisquer formalidades ou condiçōes que não as postas pelas próprias normas constitucionais.

Em suma, compete exclusivamente às Assembléias Legislativas, com sanção dos respectivos Governadores, por meio de Leis Complementares, declarar a transcendência de um interesse local em interesse comum, para os fins de integrar as funções que dizem respeito ao atendimento homogêneo de uma região geo-sócio-econômica, que se entenda pela circunscrição territorial de mais de um município, com a tríplice missão de organi- zá-las, planejá-las e executá-las (art. $25, \S 32$, in fine).

\section{A DISCIPLINA CONSTITUCIONAL DA ÁGUA E OS SERVIÇOS PÚBLICOS DE SANEAMENTO}

A Constituição de 1988 considera a água sob três aspectos: o geo-económico, como recurso natural; o de serviços públicos, como elemento primário do saneamento básico; $\mathrm{e}$ o ecológico, como fator essencial de equilibrio ambiental.

Esses aspectos são tratados em diferentes dispositivos, o que leva a imbricarem-se e interpretarem-se, os respectivos princípios e preceitos, exigindo, como regra de boa exegese, que se assegure, a cada um deles, $o$ máximo de efetividade.

Assim é que, enquanto recurso natural, a Constituição:

a) partilha o seu domínio entre a Uniāo e os Estados (arts. 20, III e 25, $3^{2}$ );

b) atribui competência legislativa privativa para legislar sobre águas (art.22, IV);

c) atribui competência à União para instituir sistema nacional de gerenciamento de recursos hídricos e definir critérios de outorga de direitos de seu uso (art. 21, XIX).

Enquanto elemento primário do saneamento básico, a Constituição:

d) atribui competência à Uniāo para estabelecer diretrizes em nível nacional (art. 21, $\mathrm{XX)}$;

e) atribui implicitamente competência aos Municípios para prestar serviços de água onde prevaleça o interesse local (art. 30, V); e

f) atribui competência aos Estados para definir as regiōes metropolitanas, as aglomeracões urbanas e as microrregiōes, nas quais deva prevalecer o interesse comum sobre o local (art. 25, § 32).

Finalmente, enquanto fator essencial de equilíbrio ambiental, a Constituição:

a) atribui competência concorrente limitada à União e aos Estados para legislar sobre a conservação de recursos naturais e meio ambiente (art. 24, I);

b) atribui aos três níveis federativos com- 
petência administrativa para proteger o meio ambiente (art. 23, VI);

c) atribui aos Estados competência para executar funções públicas de interesse comum (art. 25, \& 39).

$\mathrm{Da}$ relação oferecida, depreende-se que compete ao Estado membro desempenhar variadas funçōes atinentes à água, ora em caráter ordinário, ora em caráter extraordinário, ora em ambos, cumprindo, portanto, defini-las clara e sinteticamente, como a seguir é feito. Compete ao Estado:

Assim, compete ao Estado:

\section{I-Ordinariamente}

Conceder outorga de uso de água (captação, derivação e extração)

Para tanto, deverá o Estado conceder, no âmbito de seu território e para todos os seus municípios, agora, na forma da Lei Federal pertinente, $\mathrm{n}^{2}$ 9.433, de 8 de janeiro de 1997 , com o objetivo de "assegurar o controle quantitativo e qualitativo dos usos da água $\mathrm{e}$ o efetivo exercício dos direitos de acesso à água” (art. 11), a outorga de uso da água.

Essa outorga institui um direito público administrativo concreto à "derivação e captação de parcela de água existente em um corpo de água" (do domínio estadual, ou do domínio da Uniāo, em caso de delegação do poder concedente federal, na forma do art. $14, \S 12$ ) "para consumo final, inclusive abastecimento público, ou insumo de processo produtivo" (art. 12, I), compreendida a "extração de aqüífero subterrâneo para consumo final ou insumo de processo produtivo" (art. 12, II) (nossos, todos os destaques nos textos legais transcritos).

Sem essa outorga estadual, a derivação ou extração são ilegais.

\section{$I I-$ Extraordinariamente}

Conceder os serviços de água (em todo seu ciclo)

Sempre que se manifestar um interesse co- mum, prevalecente sobre o interesse local, o que se definirá juridicamente em lei complementar estadual que o haja regularmente definido, com a conseqüente criação de regiāo metropolitana, de aglomerações urbanas e de microrregiōes (art. 25, §3․, CF).

\section{III - Ordinariamente e extraordinariamente}

\section{Dar tratamento legal coerente à água} enquanto fator ambiental

Esta competência se exerce em todo o âmbito territorial do Estado, sempre que quaisquer atividades desenvolvidas no ciclo do uso da água, seja por particulares, seja por entidades estatais, como o são os municípios nele compreendidos, possam interferir diretamente na manutenção do meio ambiente ecologicamente equilibrado (art. 225, caput, CF).

Em síntese, o Estado-membro poderá exercer competências ordinárias e extraordinárias.

Exercerá ordinariamente sua competência constitucional ambiental, na captação, na derivação e na extração, que estão a seu cargo, e quando couber, também na produção e na adução.

Exercerá extraordinariamente sua competência constitucional ambiental, na distribuição, sempre que se manifestar o interesse comum ambiental prevalecente sobre o interesse local, exigindo o desempenho homogêneo de funções comuns, nesta hipótese, segundo a previsão expressa e na forma que vier a ser prescrita na Lei Complementar estadual instituidora de região metropolitana, aglomeração urbana ou microrregiāo.

\section{A CARACTERIZAÇĀO DO INTERESSE PREDOMINANTE COMO CRITÉRIO DEFINIDOR DA COMPETÊNCIA PARA A PRESTAÇÃO DE SERVIÇOS PÚBLICOS}

Retira-se do que foi até agora exposto, que há um falso problema federativo quanto à 
repartição de competências para o abastecimento de água e o serviço de esgoto, pois a regra continua sendo a da autonomia municipal, observada apenas a dominialidade estadual ou federal da água, conforme o caso.

Mas esta regra se excepcionará, caso venha a emergir um interesse comum, de extensão geográfica, política e jurídica, que se caracterize legalmente como antitético e derrogatório do interesse local municipal, cabendo, neste caso, ao Estado-membro, declará-lo e dispor sobre seu atendimento.

Como se percebe, a chave do problema se cinge a precisar os conceitos jurídicos de interesse local (municipal) e comum (metamunicipal), uma vez que são esses os pressupostos ou da titularidade ordinária. dos $\mathrm{Mu}$ nicípios, ou da extraordinária, dos Estados.

1. Caracterização do interesse local

A expressão interesse local vem utilizada na Constituição vigente tanto para balizar a atividade legislativa (art. 30, I) como a atividade administrativa (art. 30, V).

Trata-se de uma cláusula geral, com acentuado conteúdo fático, que veio substituir, no texto constitucional, a fórmula tradicionalmente empregada do peculiar interesse, que foi por último consignada no artigo 15 , II, da Constituição de 1967 , com a redação que lhe deu a Emenda n 1, de 17 de outubro de 1969 , tal como encontrada nas Cartas anteriores.

$\mathrm{O}$ entendimento do que fosse esse peculiar interesse pacificou-se na doutrina constitucional brasileira, muito devendo à lúcida lição de Sampaio Dória: “ Peculiar não é nem pode ser equivalente a privativo... A diferença está na idéia de exclusão: privativo importa exclusão e peculiar não...O entrelaçamento dos interesses dos municípios com os interesses dos Estados, e com os interesses da Nação, decorre da natureza mesma das coisas. O que os diferencia é a predominância, e nāo a exclusividade".'

No mesmo sentido, reafirmando que " $O$ que define e caracteriza o 'peculiar interesse', inscrito como dogma constitucional, é a predominância do interesse do Município sobre o do Estado ou da União", Hely Lopes Meirelles, o notável sistematizador do Direito Administrativo brasileiro no período do Segundo Pós-Guerra, em sua consagrada obra Direito Municipal Brasileiro, lembra que os publicistas estrangeiros também definem o interesse local pela predominância, enunciando-o apenas de maneira diversa:

"Para o clássico Black, tais interesses se referem aos negócios internos das cidades $\mathrm{e}$ vilas (internal affairs of towns and counties); para Bonnard, o peculiar interesse é o que se pode isolar, individualizar-se e diferençar-se dos de outras localidades; para Borsi, é o que não transcende os limites territoriais do $\mathrm{Mu}$ nicípio; para Mouskheli é o que não afeta os negócios da administraçāo central e regional; para Jellinek é o interesse próprio da localidade, oriundo de suas relações de vizinhança" 2

Substituída, pela Carta de 1988, a antiga expressão, peculiar interesse, pela nova, interesse local, passou-se a perquirir se a doutrina estaria diante de um conceito legalmente inovador e quiçá revolucionário nas relações intrafederativas.

Os constitucionalistas atuais que tocaram no assunto, como, por exemplo, Michel Temer $^{3}$, não lograram ver diferenças perceptíveis, subentendendo-se que consideraram as expressões idênticas, como idêntica deve ser a exegese.

Mas, se é certo que o que seria considerado peculiar ao município deva ser hoje entendido como local, pode haver, ao revés, dúvida se

1 Sampaio Dória, Autonomia dos Municípios, in Revista da Faculdade de Direito do Município de São Paulo, XXIV/419.

2 HELY LOPES MEIRELLES, Direito Municipal Brasileiro, São Paulo, Revista dos Tribunais, 1985 , $5^{\mathrm{a}}$ ed., ps. 76 e 77.

3 MICHEL TEMER, Elementos de Direito Constitucional, São Paulo, Revista dos Tribunais, 1989, 5a edição, p.105. 
tudo o que é local pode ser considerado como peculiar.

De lege lata, o conceito de local tem, por isso, um conteúdo geográfica e politicamente mais delimitador, que se ampliará, sucessivamente, no de regional e no de nacional ${ }^{1}$, ao considerar-se a tríplice partilha vertical de poder estatal do sistema federativo brasileiro (art.18, CF).

Finalmente, mas nem por isso menos importante, pois até se deixou por último para destacá-lo, é preciso atentar-se para o sentido dinâmico contido na nova expressão constitucional, interesse local.

Com efeito, o entendimento do que seja interesse local mostra-se mais sensível que a expressão anterior, peculiar interesse, às transformações tecnológicas e econômicas e parece ter mais flexibilidade para assimilálas, pois o que é hoje local, amanhã poderá ser regional e, depois, quiçá nacional ou, até mesmo, transnacional, quiçá, 'comunitário', como já o é na Europa hoje e poderá ser, amanhã, no Cone Sul.

Com notável preciência, Adilson de Abreu Dallari, trazendo à colação estudo de José Afonso da Silva, já apontava esta qualidade metamórfica em 1970, em passagem que se mantém absolutamente atual e apropriadíssima:

"Todavia essa afirmação" (da predominância) "traz imediatamente a conclusão de que o conceito de peculiar interesse é essencialmente dinâmico, de vez que a predominância de interesse, como se observa na prática, varia e efetivamente tem variado no tempo e no espaço." 2

Com essas achegas doutrinárias, já se pode tabular alguns elementos para identificar o interesse local dos municípios: ria);

1. a predominância do local (Sampaio Dó-

2. ser interno às cidades e vilas (Black);

3. que se pode isolar (Bonnard);
4. territorialmente limitado ao município(Borsi);

5. sem repercussão externa ao município (Mouskheli);

6. próprio das relações de vizinhança (Jellinek);

7. simultaneamente oposto a regional e nacional e

8. dinâmico (Dallari).

\section{Caracterização do interesse comum}

Distinto e até, de certo modo, em oposição ao interesse local institui-se, também, em sede constitucional, o interesse comum de características regionais, mas de âmbito menor que o interesse estadual.

A expressāo deste interesse comum se encontra explicitada no artigo $25, \S 32$, da Constituição de 1988, com o mesmo conteúdo que, também explicitamente, surgiu, pela primeira vez, no texto constitucional brasileiro, no artigo $157, \& 10$, da Carta de 1967, muito embora tivesse ficado implícita no texto intermédio, na locução "realização de serviços comuns", do art. 164, com a redação que lhe deu a Emenda n 1, de 17 de outubro de 1969.

Como o mesmo instituto se repete, inserindo-se hoje no art. 25, que elenca competências estaduais, no Capítulo III, Dos Estados Federados, por sua vez, parte do Título III, Da Organizaçāo do Estado, a leitura sistemática não nos deixa dúvida de que o interesse comum que é nele considerado é o que transcende o municipal e passa a ser considerado estadual, e tanto assim o é, que cabe exclusivamente à Assembléia Legislativa do Estado, que o reconhecer, declará-lo formalmente, em lei complementar.

Por transcender, por ser distinto e até, de certo modo, por manifestar-se em oposição

1 Prosseguindo-se além, como interesse transnacional, que poderá ser, ainda, genericamente internacional ou, especificamente, comunitário.

2 ADILSON DABREU DALlARI, O Uso do Solo Metropolitano, in Revista de Direito Público, V. 14, outubro/dezembro de 1970, p. 289. 
em relação ao interesse local, esse interesse comum apresenta aspectos peculiaríssimos.

Com efeito, ao se aplicar, para caracterizálo, a mesma tabulação acima organizada para situar o interesse local, encontrar-se-āo, no cotejo, notáveis diferenças, pois o interesse comum:

1. apresenta predominância do regional;

2. se externaliza às cidades e às vilas;

3. não está isolado;

4. nāo está territorialmente limitado ao município;

5. tem repercussão externa ao município;

6. transcende as relações de vizinhança;

7. é simultaneamente oposto ao local e ao nacional;

8. está estabilizado por uma definição legal específica.

Essa última característica marca positiva e claramente a distinção que se pretende ressaltar, uma vez que, de um lado, o interesse local vem a ser uma cláusula geral, sujeita à dinâmica dos fatos e interpretaçōes históricas, enquanto que, por outro lado, o interesse comum se apresenta estabilizado por uma cláusula legal específica que o define.

$O$ interesse comum, "predominantemente regional e portanto comum a mais de um Município", que na vigência da Carta anterior seria apenas um interesse comum metropolitano $^{2}$, veio a desdobrar-se, no art. $25, \S 32$, da Constituição de 1988, em três tipos: o interesse comum metropolitano, o interesse comum de aglomeraçōes urbanas (conurbano) e o interesse comum de microrre-giões.

Identificada a existência do interesse comum, agora com a qualificação de metropoli . tano, cumpre estabelecer a instrumentalidade do instituto correlativo da região metropolitana.

\section{AS REGIÕES METROPOLITANAS COMO INSTRUMENTOS DO INTERESSE COMUM}

\section{As regiões metropolitanas em geral}

A origem do conceito de região metropolitana remonta à moderna definição de cidade e aos subsídios trazidos pela Ciência do Urbanismo. Já na Carta de atenas, documento consolidador que até hoje norteia os estudos e os planejamentos urbanos, conceituava-se a cidade em função da região:

" A cidade não é senão uma das partes do conjunto econômico, social e político, que constitui a regiāo. A unidade administrativa raramente coincide com a unidade geográfica. Não se pode resolver um problema de urbanismo, sem referência constante à Regiāo". 3

O fenômeno da conurbação, como prosseguimento da urbanização, acentuou ainda mais a necessidade de atentar-se para a escala regional de prestação de serviços como condição essencial para proporcionar-se um tratamento homogêneo, eficiente e módico às funçōes urbanas que transcendem as dimensões físico-sociais da cidade tradicional.

Por não encontrar solução no federalismo clássico, os problemas suscitados pela expansão dos centros urbanos, notadamente preocupantes no Brasil depois do Segundo PósGuerra, demandaram uma alternativa constitucional que com ele se compatibilizasse.

Embora o instituto da Regiāo Metropolitana, ainda sem esta denominação, recebesse

1 As Leis Complementares instituidoras ou reinstituidoras, com modificações, de Regiōes Metropolitanas, bem como de Aglomeraçōes Urbanas e de Microrregiões, especificam as funçōes de interesse comum, como se pode verificar, como exemplo, na relação do art. $5^{\circ}$, da Lei Complementar $n^{2} 14$, de 8 de junho de 1973, que estabeleceu as primeiras Regiōes Metropolitanas do País, até hoje todas existentes.

2 A citaçāo e a expressão são de EURICO DE ANDRADE AZEVEDO, A Gerência da Área Metropolitana, in Revista da Procuradoria Geral do Estado do Rio Grande do Sul, 9 (24), 1979, p. 19.

3 CARTA DE ATENAS, apud, HELY LOPES MEIRELLES, Limitaçōes urbanisticas ao uso da propriedade, RDA, 52, p. 16. 
um pálido ensaio na Constituição de 1937, ele somente voltaria a aparecer trinta anos mais tarde, como uma previsão de agrupamento de municípios da mesma região para administrar seus interesses comuns.

Por inspiração e sugestão de Hely Lopes Meirelles, uma emenda aditiva, proposta pelo Senador Eurico Rezende, ao Projeto de Constituição submetido ao Congresso Nacional em 1966 , veio a se transformar no art. $157, \S 10$, da Constituição de 1967, introduzindo-o com a configuração próxima da que hoje tem. ${ }^{1}$

O dispositivo previa lei complementar da União para criar regiões metropolitanas, que seriam constituídas por municípios integrantes da mesma comunidade sócio-econômica, visando à realização de serviços de interesse comum, tendo sido reproduzido, com pequena alteração, no art. 164 da Emenda Constitucional n² 1 , de $1969 .^{2}$

$O$ instrumento infraconstitucional de criação de regiōes metropolitanas, que fora previsto em 1967 e mantido em 1969, só seria editado sete anos mais tarde, com a Lei Complementar $n^{2} 14$, de 8 de junho de 1973, instituindo oito Regiōes Metropolitanas ${ }^{3}$, regulando-lhes a estrutura e o funcionamento.

Seguiram-se mais duas Leis Complementares: a de $n^{2}$ 19, de 25 de junho de 1974, que acrescentou a criação da Região Metropolitana do Rio de Janeiro, e a de $n^{2} 27$, de 3 de novembro de 1975 , que apenas alterou o artigo $2^{\circ}$ do texto da Lei Complementar $n^{2} 14$, de 8 de junho de 1973, dispondo sobre o Conselho Consultivo.

Observe-se que já cabia, desde então, à norma infraconstitucional de cada Estado, discriminar os serviços de interesse comum, definindo o que seriam os serviços metropolitanos a serem unificados.

Viria a ser esse, o embriāo do atual sistema descentralizado, posteriormente adotado pela Constituição de 1988 , no seu art. $25, \S 32$, que, mantendo e ampliando o instituto das regiōes metropolitanas, com o acréscimo das aglomerações urbanas e das microrregiōes, deslocou a competência para institui-las e disciplinálas, retirando-a da Uniāo para deferi-la aos respectivos Estados-membros.

Como se depreende do breve histórico, o instituto da região metropolitana veio à luz, desde seus primeiros ensaios, com a finalidade, bem definida, de estabelecer um pólo de concentração de competências, tendo como objetivo possibilitar um tratamento homogêneo de atividades administrativas desenvolvidas num conjunto urbano homogêneo, formado por vários Municípios.

Concebeu-se uma forma que, sem que se tivesse de criar um ente político intermediário entre o Estado e o Município, o que avançaria para um federalismo de quatro níveis, preferiu-se instituir um pólo de imputação de poder estatal despolitizado, embora suficientemente aparelhado para atender a essa categoria intermediária de interesses considerados no contexto federativo.

Consideram-se, especificamente, esses interesses intermédios, que transcendem o interesse local, próprio de cada Município, sem chegarem, contudo, a ser um interesse regional, ou seja, atinentes a todo o Estado.

Constituem-se, por isso mesmo, numa classe a parte, de interesses comuns transmunicipais, que, não podendo ter definição e tratamento municipais, nem existindo entidade política intermediária que deles se ocupem, passam a depender de definição política $e$ tratamento estadual.

Enquanto centro despersonalizado de imputação de poder estatal, a região metropolitana, como suas congêneres, não são, insistase, uma nova entidade da federação, embora constituindo, necessariamente, um órgão, não importa se personalizado ou não, conforme a livre opção do legislador estadual, podendo

1 Cf Anais da Constituição de 1967, Senado Federal, Brasília, 1970, v. 6, t 2, ps. 913/914.

2 Este histórico se encontra desenvolvido por RAUL MACHADO HORTA, em Regiōes Metropolitanas e o Direito Constitucional Brasileiro, Revista de Direito Público, n² 29, ps. 9 e ss.

3 São Paulo, Belo Horizonte, Porto Alegre, Recife, Salvador, Curitiba, Belém e Fortaleza. 
até ser um conjunto de vários órgãos, se houver conveniência política do Estado em atribuir-lhes, na respectiva lei complementar instituidora, setores distintos e semi-autônomos de planejamento, de gestão ou de execução das funçōes comuns a serem unificadas sob a competência integradora do Estado-membro.

Assim, se essa escolha vier a ser a instituição de um órgão executivo não personalizado, este poderá ser tanto uma Secretaria de Estado como, preferentemente, o próprio colegiado que seja instituído como Conselho Diretivo da Regiāo Metropolitana; em ambos os casos, órgãos administrativamente autônomos do próprio Estado-membro.

Se a escolha vier a ser, porém, a instituição de um ou mais órgãos executores personalizados, a Lei Complementar se lhes poderá atribuir personalidade de direito público, sob a forma de uma ou de várias autarquias, já existentes ou a serem organizadas para esse fim, também pelo Estado-membro, ficando, conseqüentemente, a ele vinculadas, em obediência ao comando do art. 37 , XIX, da Constituição, que exige lei específica (sempre do Estado) para criá-las.

Finalmente, ainda no caso da escolha recair sobre a instituição de um ou mais órgãos gestores, se lhes poderá, alternativamente, atribuir personalidade de direito privado, sob a forma de entidades paraestatais, já existentes ou que venham a ser organizadas para esse fim, mas sempre por lei do Estado membro e, do mesmo modo, a ele vinculadas, em razão do comando do art. 37, XIX, da Constituição, que exige lei autorizadora.

De modo destacado, essa necessária estadualidade das instituições executoras das atividades a cargo das Regiōes Metropolitanas foi captada, com singular clareza, na Lei
Complementar $n^{2} 26$, de 14 de janeiro de 1993, do Estado de Minas Gerais, que assim dispōe sobre a Região Metropolitana de Belo Horizonte:

"Art. 30.

$\S$ I $^{0}$ O Estado assegurará a execução de planos, programas e projetos relacionados às funções públicas de interesse comum no âmbito metropolitano, por meio e instituiçōes da administração pública estadual."

Inescapável, portanto, a estadualidade de qualquer órgão deliberativo ou executivo de uma região metropolitana, valendo a mesma afirmação quanto aos institutos congêneres, das aglomeraçōes urbanas e das microrregiões, que igualmente se situam em territórios estaduais, sendo oportuno aqui recordar, a respeito, que apenas União, Estados e Distrito Federal possuem territórios, no sentido técnico, pois os âmbitos político-administrativos dos Municípios constituem-se em circunscriçōes, com suas respectivas terras apenas sob dominialidade administrativa e não dominialidade política. ${ }^{\prime}$

Este é o sentido que se lhe deve dar ao ensinamento de Hely Lopes Meirelles, em sua conhecida passagem sobre a natureza jurídica da organização das regiōes metropolitanas ${ }^{2}$, com o qual também coincide o magistério recente de Caio Tácito, que aqui se transcreve:

"A Região Metropolitana não é, contudo, uma entidade política intermediária entre o Estado e o Município, mas apenas uma área administrativa de serviços especiais, cuja administração poderá ser atribuída a uma pessoa administrativa autárquica ou paraestatal, ou mesmo a órgão da administração direta estadual." 3

1 V. art. 20, II, e art. 26, IV, da Constituição.

2 HELY LOPES MEIRELLES, Direito Municipal Brasileiro, São Paulo, Ed. Malheiros, 1993, $6^{\text {a }}$ ed. p. 75 .

3 CAIO TÁCITO, Saneamento básico - Regiāo Metropolitana Competência Estadual, Revista de Direito Administrativo, $\mathrm{n}^{2} 213$, jul./set. 1998, p. 325. O ilustre Mestre traz, exabundantemente, à colação, no mesmo sentido, além de HELY LOPES MEIRELLES (Direito Municipal Brasileiro), EURICO DE ANDRADE AZEVEDO (Instituição de Regiōes Metropolitanas no Brasil, Revista de Direito Público, 2/196) e ROBERTO ROSAS (Perspectiva Jurídica da Regiāo Metropolitana, Revista de Direito Público, 
2. Recepção da legislação complementar federal sobre Regióes Metropolitanas no ordenamento constitucional inaugurado em 1988

O princípio da continuidade jurídica assegura a vigência das Regiōes Metropolitanas criadas pela União, segundo as prescrições da Constituição anterior, que lhe deferia competência para institui-las, salvo naqueles dispositivos que eventualmente passaram a colidir com a competência transferida aos Estados.

A questão da recepção das regiões metropolitanas já se pode considerar superada, julgada que foi por decisão unânime, no Superior Tribunal de Justiça, Corte constitucionalmente competente para examinar a compatibilização da legislação federal vigente antes da Constituição de 1988 com a nova ordem constitucional introduzida, no Recurso Ordinário em Mandado de Segurança n 314/MG, em 17 de outubro de 1994.

Na Ementa do Acórdāo, o Ministro Demócrito Reinaldo deixou bem definida a tese, hoje indisputada:

"É princípio do direito pátrio de que a lei somente será revogada por outra subsequiente. Enquanto não editada a lei complementar estadual disciplinando a criação, organização e funcionamento das regiōes metropolitanas, continua a vigorar a Lei Complementar $n^{2}$ $14 / 73$, que regula a matéria"

Em consequiência, aos Estados que tiveram regiōes metropolitanas instituídas em seus territórios por leis complementares federais, na vigência da ordem constitucional anterior, abriram-se, a partir da Carta de 1988, as alternativas de ratificá-las, ratificá-las parcialmente ou extingui-las.

\section{A Região Metropolitana de Belém}

A Regiāo Metropolitana de Belém foi uma das criadas pela Lei Complementar Federal $\mathrm{n}^{2} 14$, de 8 de junho de 1973, e recepcionadas pela Carta de 1988, tendo sido ratificada pelo Estado do Pará, no exercício da competência transferida para os Estados, pela Lei Complementar Estadual $n^{2} 27$, de 19 de outubro de 1995, que lhe introduziu modificações.

Neste sentido, a opção exercida pelo legislador paraense foi a de ratificá-la com alterações. Quanto a essas inovaçōes de substância introduzidas, não obstante certo laconismo que se lhes possa reparar, a Lei Complementar Estadual referente à Região Metropolitana de Belém, mantêm todos os elementos necessários para sua operacionalização, a saber:

1. a indicação dos Municípios que a constituem: Belém, Ananindeua, Marituba e Benevides (art. $1^{\circ}$ );

2. a instituição de um Conselho Metropolitano, discriminando seus membros e os cargos de Presidente (Governador do Estado) e Vice-Presidente (Secretário de Estado de Planejamento) (art. $2^{2}$ );

3. a instituição de uma Secretaria Geral, administrada por um Secretário-Geral nomeado pelo Governador (art. $2^{2}, \S 1^{2}$ );

4. a disciplina do custeio das despesas de funcionamento do Conselho Metropolitano, à conta do orçamento estadual (art. $2^{\mathrm{o}}, \S 2^{2}$ );

5. a previsão de decreto regulamentar (estadual) sobre o funcionamento do Conselho Metropolitano (art. 39);

6. a criação do Fundo de Desenvolvimento da Região Metropolitana de Belém (estadual), cuja receita é determinada pelo Conselho;

7. a unificação do planejamento e da execução de serviços comuns (art. 5).

Ao tratar da unificação dos serviços comuns da Regiāo Metropolitana, a Lei Complementar estadual admitiu a adoção de qualquer uma das seguintes três modalidades executivas que ela própria discrimina (art. 52, parágrafo único):

$1^{2}$ a execução "pela concessão do serviço da entidade estadual";

28/89). O itálico na citaçāo é nosso, para chamar a atenção para o fato de que, na hipótese da COSANPA, tem-se uma paraestatal estadual, delegatária de serviços públicos de interesse metropolitano. 
$2^{2}$ a execuçāo "por empresa metropolitana a ser constituída";

32 a execução "por outros processos que, através de convênio, venham a ser estabelecidos".

Prevalece, assim, a primeira alternativa, segundo a qual a execução do serviço da entidade estadual, a CONSULENTE, é mantida, enquanto a entidade diretora, que é o Conselho Metropolitano, não houver por bem adotar outra.

Com efeito, a modalidade de prestação do serviço comum metropolitano de água e esgoto, executado através da CONSULENTE, na qualidade de delegatária legal do Estado do Pará, se quadra entre aquelas genericamente admitidas no art $5^{\circ}$, parágrafo único, da Lei Complementar Estadual $n^{\circ} 27$, de 19 de outubro de 1995.

A CONSULENTE, a entidade estadual referida na Lei Complementar, na qualidade de delegatária legal do Estado do Pará, poderá, por seu turno, dependendo apenas de decisāo do orgão gestor metropolitano, concedê-la particulares, o que também está autorizado na expressão "concessão do serviço da entidade estadual", que sufraga as duas possibilidades de execuçāo: direta e concessional, modalidades que, como adiante se examinará em destaque, foram ambas previstas constitucionalmente.

A Lei Complementar estadual ratificatória confirmou, portanto, a outorga, ao Conselho Metropolitano, da faculdade discricionária nāo só de determinar qual das três opões abertas seria a de maior conveniência, como, ao nāo lhe assinar qualquer prazo, de definir a oportunidade de fazê-lo.

Considerou, por certo, o legislador complementar, que a criação de novos orgãos e entidades, mormente para duplicar funções e serviços que já vinham sendo executados, importam sempre em redobrados dispêndios de recursos públicos, sabidamente escassos, fato que se tomou mais crítico nessa quadra de rigorosos ajustes fiscais em todo o País.

É indubitável que, sem qualquer constrição de prazo, que poderia ter sido fixado na Lei Complementar, a opção política provisória, de manter a execuçâo com a entidade esta- dual, na qualidade acrescida de delegatária metropolitana, foi e segue sendo não só legítima como a mais prudente.

Com efeito, enquanto não se reconhecem politicamente as condições técnicas e financeiras, para que possa vir a ser de futuro considerada, escolhida e implementada qualquer uma das formas de execução previstas, a opçāo de manter o serviço integrado sob a execução da paraestatal estadual, a CONSULENTE, que tradicionalmente o presta, não parece ter sido apenas a decisāo mais racional e eco. nômica, dada a assentada experiência da empresa estadual delegatária, como pelo fato de que a manutenção do status quo não implica em despesas imediatas, melhor prestando-se para dar tempo ao Conselho Metropolitano para desenvolver equacionamento e planejamento cuidadosos.

Destarte, a delegação legal, outorgada à CONSULENTE pela Lei Estadual n 4.336, de 21 de dezembro de 1970, para a execução da prestaçāo de serviços públicos de abastecimento de água e de esgotos sanitários $\mathrm{em}$ todo o Estado, tornou-se específica para a Região Metropolitana Belém, por força da instituição originária deste órgão, em 8 de junho de 1973, e permaneceu vigentc, confirmada que foi pela Lei Complementar estadual de 27 de novembro de 1995.

Sublinhe-se, portanto, que esta vigência, imodificada e imperturbada, permanecerá as. sim inalterada enquanto não vierem a ser preferidas e adotadas, pelo órgāo gestor metropolitano competente, quaisquer das outras opções previstas na Lei Complementar $n^{0} 27$, de 19 de outubro de 1995, ou outras modalidades de execução não sejam acrescentadas em nova Lei Complementar estadual.

\section{A IMPORTÂNCIA JURÍDICA E METAJURÍDICA DA EQUALIZAÇÃO DE TARIFAS}

A admitir-se, por hipótese, a possibilidade jurídica de uma ruptura unilateral, por decisão municipal, da integração existente do serviço público de água e esgoto, instituído na área que hoje conforma a Região Metropoli- 
tana de Belém. dando-se a fragmentação dos serviços entre as quatro unidades municipais que a constituem, tudo em áreas da preservação à outrance da titularidade local dos serviços, como vem sendo alegado pelo Município de Belém, não só se estaria esvaziando a eficácia do art. $25, \S 3^{2}$, da Constituição, como, acrescidamente, perpetrando uma aberta e direta violação, ainda mais grave, a seu princípio fundamental, que determina ao Poder Público atuar no sentido de reduzir as desigualdades sociais e regionais (art. 32, III, CF).

E aqui se chega a um aspecto constitucional que toca profundamente o seu conteúdo de valor.

Com efeito, os serviços públicos de água e esgoto somente vêm sendo prestados, de longa data, para toda a Grande Belém, graf̧as à unidade de planejamento e de execuçāo, que permitiu a indispensável concentração de meios e economicidade de resultados, embora ainda reconhecidamente insuficientes, por falta de maiores investimentos.'

A simples verificação superficial das condições de prestação desses serviços, a quem quer que se disponha a deles se inteirar, mostra que, não obstante tudo o que se logrou realizar, não sem durezas e sacrifícios, em regime de integração voluntária, na hipótese de se fragmentarem e de se dispersarem entre os Municípios que conformam a Região Metropolitana de Belém, como pretende o Município da Capital, a primeira das gravíssimas conseqüências sociais que advirão será a desigualação dos usuários.

Não é preciso grande esforço prospectivo para antecipar-se que, a prosperar essa pretensão isolada, de um dos Municípios da Regiāo Metropolitana, e logo o relativamente mais rico, o de Belém, que já possui consolidada a maior malha de distribuição e a maioria das facilidades industriais da região, ele pró- prio, será o único beneficiário, pois, possivelmente, poderá continuar a desfrutar de seus serviços de água e esgoto no mesmo nível tarifário atual e, quiçá, poderá ainda contar, de futuro, com recursos sobejantes, para melhorá-los.

Mas, em agudo contraste, por outro lado, as cidades-satélite da Capital, constituídas pelos Municípios de Ananindeua, Marituba e Benevides, justamente os de menor renda e de infraestrutura mais precária, não só terão seus custos tarifários de saneamento imedia. tamente elevados, mesmo se for o caso de simplesmente manter os serviços existentes, como ficarão na iminência de tê-los deteriorados, por falta dos necessários recursos, que estejam disponíveis em cada um deles, para duplicar ou triplicar todas as instalaçōes de que necessitarão para atendê-los

Em termos simples e realistas: a estranha obstinação do Município de Belém em ignorar a natureza comum, a que constitucionalmente estão vocacionados esses serviços metropolitanos e a inelutável racionalidade das economias de escala, acabará condenando milhares de usuários dos municípios vizinhos mais pobres a pagar muito caro pelos respectivos serviços locais de água e esgoto $\mathrm{e}$, a médio prazo, suportar os incômodos e sofrimentos decorrentes de sua falta, enquanto o Município da capital auferirá, unilateralmente, como legatário privilegiado, os benefícios de dois séculos de trabalho².

Esta atitude, observe-se, não é apenas, como poderia parecer à primeira vista, egoística e carente de solidariedade, merecendo ser verberada em sede política e moral, o que seria, até este ponto, insindicável pelo Poder Judiciário. $O$ que aqui importa, é que ela manifesta uma pretensão visceralmente inconstitucional, porque agride a letra $e$ o espírito do princípio fundamental do art. 30, III, que, ao orientar positivamente o uso do Poder

1 Cf., a respeito, a obra Macrodrenagem e Água Potável em Belém do Pará. Belém, 1994, Editora Multsoft.

2 V. Macrodrenagem e Água Potável em Belém do Pará, op. cit. p. 11. 
Público para reduzir as desigualdades regionais, veda, a contrario sensu, tudo o que se disponha, negativamente, no sentido de agravá-las.

Ora, quando a Constituição institui princípios fundamentais, não o faz sem eficácia jurídica. Neles se aninham, sobretudo, elevados direitos difusos dos cidadãos de que o Estado os concretize, em seus atos legislativos e administrativos.

J.J. Gomes Canotilho, a respeito, tem liçāo adequada:

"...impōem-se constitucionalmente aos órgãos do Estado (sobretudo ao legislador), de forma permanente e concreta, o cumprimento de determinadas tarefas, fixando-se, inclusive as directivas materiais." 1

Merece igualmente acompanhamento o magistério de Robert Alexy, que tão penetrantemente tem tratado desse fascinante tema na doutrina contemporânea, ao afirmar que " $\mathrm{A}$ institucionalização inclui necessariamente justicialização". ${ }^{2}$

Assim, sem que seja possível ao Judiciário tutelar essa norma-princípio, que constitucionaliza um lídimo direito difuso da cidadania, para que a ação do Estado pelo menos não prejudique a redução das desigualdades regionais, nāo importa como apareçam na legislação e na administração, sua expressão não passará de uma declaração insonte, de um mero norte fílosófico, no máximo da indicação de um caminho programático, mas jamais se impondo, como solenemente proclamado, como um princípio fundamental.

$E$ não se estranhe a insistência nesta invocação principiológica, que aqui se apresenta como argumento de reforfo para lastrear a interpretação que se apresenta como a mais consentânea com a própria razāo de instituírem-se essas soluçōes agregativas regionais, previstas no art. $25, \S 32$, da Constituição.

Além das expostas, há sobejas razões para sustentar essa via interpretativa adotada, pois a moderna Ciência do Direito, ao transcender, no século vinte, o formalismo e o positivismo jurídico, construídos quase exclusivamente sobre coleções de preceitos, em que predominaram as estruturas de conhecimento do tipo neo-kantiano, estão, perceptivelmente, deslocando o seu pressuposto de praticabilidade para o conceito funcional de sistema, estruturado predominantemente sobre uma rede articulada de princípios.

Claus-Wilhelm Canaris, um dos mais destacados doutrinadores do pensamento sistêmi$c o$, aponta, nessa linha, as duas grandes vertentes modernas e contemporâneas que nela confluem: o jusracionalismo, como manifestação do jusnaturalismo tradicional, e o cientismo, como transposiçāo, para as Ciências Humanas, de metodologias e, notadamente de posturas epistemológicas desenvolvidas no domínio das Ciências da Natureza. ${ }^{3}$

Essas influências já representam, em plena "Era da Informaçāo", como denomina Manuel Castells ${ }^{4}$ a essa época de transição do século vinte para o vinte e um, um movimento de síntese gnoseológica, possivelmente irreversível, em que o pensamento sistêmico pervade todas as ciências, as integra e lhes permite uma elevada mobilidade de critérios, com o abandono das previsões normativas e do cultivo dos sistemas fechados, impérvios aos fatos mais recentes e aos novos dados

1 J.J.GOMES CANOTILHO, Direito Constitucional, Coimbra, Ed. Almedina, 1991, $5^{\mathbf{2}}$ ed. p. 185

2 ROBERT ALEXY, Colisāo de Direitos Fundamentais e Realização de Direitos Fundamentais no Estado de Direito Democrático, palestra proferida na Escola Superior da Magistratura Federal, no dia 7 de dezembro de 1998, publicada na Revista de Direito Administrativo, $\mathrm{n}^{0} 217$, julho-setembro de 1999 , p.73 (n/grifo).

3 Cf. ClaUS-WILHELM CANARIS, Pensamento Sistemático e Conceito de Sistema na Ciência do Direito, Lisboa, 1966, tradução do original Systemdenken und Systembegriff in der Jurisprudenz, Ed. Calouste Gulbenkian.

4 Cf. MANUEL CASTELLS, La Societé en réseaux; l'ère de l'information, Paris, Ed. Fayard, 1996. 
metajurídicos, que se desenvolvem exponencialmente e demandam permanentes e lúcidas aberturas.'

O Direito, de talho formalista e positivista, herdado do século dezenove, com sua carga de preceitos rígidos e inflexos, cede a um Direito móvel e dúctil, que já se reconhece facilmente nas construções sistemáticas mais modernas, notadamente naquelas que já começam a demonstrar a absorção de valores e princípios metajurídicos de reconhecida importância e vigência social.

A necessidade de haurir esses novos valores e princípios metajurídicos, para fazer face aos problemas constantemente suscitados pelo progresso e complicados pela crescente complexidade da vida em sociedade, é cada vez mais permanente e demandante.

Arriscam-se à rápida obsolência, legisladores e profissionais do direito que se quedarem antolhados pela dogmática dos conceitos e não elevarem suas vistas para a amplitude $\mathrm{e}$ a caleidoscópica cambiância desses processos sociais, sobre os quais devem operar para realizá-lo em sociedade.

Por isso, pode-se perceber, com crescente nitidez, que não só a doutrina, como o direito positivo já começam a exibir essa expansiva absorção sistêmica de conceitos, métodos, valores e princípios metajurídicos, pelos mais variados processos autopoiéticos, podendo-se mencionar, como exemplos acabados, os princípios já completamente absorvidos da economicidade, da eficiência e da igualdade contributiva, e, como exemplos de princípios já em vias de plena absorção, a participação e a subsidiariedade.

Os dois primeiros, os princípios da economicidade e da eficiência, que datam suas origens dos avanços alcançados pelas Ciências Econômicas a partir de Adam Smith, introduzem, no mundo jurídico, parâmetros relativos de aproveitamento ótimo de recursos escas- sos, para a realização máxima de resultados desejados.

A Constituiçāo brasileira de 1988, das mais atualizadas quanto a essa orientação, já $a b$ sorveu esses dois princípios e os explicitou: respectivamente, o princípio da economicidade, no art. 70, caput, como critério para o controle da gestão financeira, orçamentária e patrimonial, e o princípio da eficiência, no art. 37, caput, dirigido à atividade administrativa em geral.

Com isso, o Direito, como Ciência do Poder, notadamente em seu ramo Público, adquiriu uma nova dimensão qualitativa, já que não se trata, apenas, de exigir que o Estado logre resultados com os meios que lhe são postos à disposição pela sociedade (eficácia), mas de que os realize o melhor que lhe for possível (eficiência).

Destacadamente, o seguinte, o princípio da capacidade contributiva, com sua origem detectada também na obra matriz de Adam Smith e reproduzida na Declaração dos Direitos do Homem, após um período de retraimento, marcado pelo fastígio do positivismo jurídico e pelas ideologias estatizantes, passou a ser cultivado pela Ciência das Finanças e pela Ciência Política, até reencontrar sua renascida expressão no Direito contemporâneo.

Do mesmo modo que os dois primeiros, o princípio da capacidade contributiva também encontrou sua explicitaçāo na Constituiçāo brasileira de 1988 , no art $145, \S 1$ 으, como a aptidão de cada um "contribuir na proporção de suas rendas e haveres, independentemente de sua eventual disponibilidade financeira" 2 (o que vem a ser a ability to pay, dos anglosaxões), introduzindo, portanto, uma diferença de extrema importância entre capacidade financeira e capacidade econômica, esta última, a expressão corretamente preferida pelo legislador constitucional brasileiro.

Os dois últimos princípios referidos, o da

I V.CLAUS-WILHELM CANARIS, op. cit. ps. 281 e 282.

2 RICARDO LOBO TORRES, Curso de Direito Financeiro e Tributário, Rio de Janeiro, Ed. Renovar, 1996, $3^{\mathrm{a}}$ edição, ps. .82e 83. 
participação e da subsidiariedade, beneficiaram-se do extraordinário desenvolvimento da Ciência Política neste século, e, mais precisamente, com os estudos da Cratologia, como Ciência do Poder, pois sāo, ambos, princípios dessumidos da observação, do estudo e da sistematização dos fenômenos do poder.

O princípio da participaçāo, produto do desenvolvimento da democracia, pertine à origem e ao exercicio do poder, afirmando sua necessária fonte na pessoa humana e, a partir desse conceito, a desejável atuação de todos nas escolhas políticas, não apenas as dos governantes (democracia representativa) mas de como se quer ser governado (democracia participativa).

O princípio da subsidiariedade, por sua vez, vem assomando em importância em relação aos problemas da concentração e, também, do exercício do poder nas sociedades política e juridicamente organizadas, ambos, este e o anterior, de extrema relevância instrumental para a plena realização do princípio finalístico substantivo da legitimidade.

Destacadamente, o princípio da participaçāo, além de ter sido reiteradamente expresso, como um princípio fundamental, em vários dispositivos, notadamente no artigo $1^{2}$, que define o Brasil como Estado Democrático de Direito, no inciso II, que proclama a base política da cidadania, e no parágrafo único do mesmo artigo, que declara a origem popular do poder político, exercitável pela representação e pela participação, ressurge em numerosos outros dispositivos constitucionais, valendo destacar, o artigo 14, do Capítulo dedicado aos direitos e garantias fundamentais, ao estabelecer as formas de participação direta e semi-direta, extensíveis ao âmbito da Administração Pública.

$\mathrm{O}$ último dos mencionados, o princípio da subsidiariedade, diz respeito à relação entre níveis de concentração de poder e respectivos níveis de interesses da sociedade a serem por ele satisfeitos. Embora se defina como um moderno princípio do poder, sua origem histórica remonta à prática política da Confederação Helvética e ao magistério da Igreja $\mathrm{Ca}$ tólica, a partir da Encíclica Quadragésimo Anno, do Papa Pio XI, que nela o enunciou claramente, tendo adquirido divulgação e importância crescentes com sua adoçāo no constitucionalismo alemão e no direito comunitário europeu.

O princípio da subsidiariedade, além de afincar-se na origem individual do poder, estende-se à sua atribuição e à sua distribuição, tanto no meio social como no meio político, informando o escalonamento sucessivo de atribuições de cada ente ou cada órgão, em função da complexidade do atendimento dos interesses da sociedade.

Assim, cabe, primariamente, aos individuos decidirem e atuarem em tudo o que se refira aos inerentes interesses individuais e, secundariamente, aos órgãos de decisão coletiva, decidirem e atuarem; primeiramente os da sociedade e, só depois, os órgãos políticos.

Do mesmo modo, aos grupos sociais menores, cabe, por sua vez, decidirem e atuarem para a satisfação dos respectivos interesses coletivos; aos grupos sociais maiores, decidirem e atuarem em prosseguimento de interesses coletivos de maior abrangência; e à sociedade civil, tomada em seu todo, decidir e atuar para realização de seus interesses gerais.

Somente aquelas demandas, que, por sua própria natureza, em razão da complexidade e da necessidade de uma ação concentrada e coercitiva, inclusive a centralizacão de recursos, não puderem ser atendidas pela própria comunidade, deverão ser cometidas à organizaçōes políticas, que atuarão, desse modo, subsidiariamente à sociedade.

Ainda assim, a sucessiva concentração de poder que deva ocorrer em todas as organizações políticas, das menores às de maior amplitude, obedecerá ao mesmo princípio: as demandas que puderem ser atendidas pela organizaçāo política local, como sejam o Município, o Condado, a Comuna etc., determinarão suas competências político-administrativas; as que nāo possam ser satisfeitas por meio de decisões e de ações locais deverão passar a organizaçāo política regional, ou intermédia, como o Estado, a Província, o Cantão, a Região Autônoma etc.; as que ultrapassem as possibilidades regionais, por sua 
generalidade ou peculiaridade, serão cometidas às organizações políticas nacionais soberanas, como a Uniāo, nos Estados Federados, o Estado Nacional etc., dotadas de todas as competências necessárias para atendê-las diretamente, bem como as de negociar com outras concentraçōes de poder, soberanas ou não, a satisfação indireta ou coordenada de interesses do País.

A adoção do princípio da subsidiariedade, embora incipiente e rústica no que toca à distribuição política de competências, que é seu ponto nevrálgico, tomada apenas como conceito, revela-se na Constituição brasileira de 1988, a partir de sua inovadora solução tripartite do poder estatal, que é estabelecida como sua marca federativa distintiva, nos art. $1^{2} \mathrm{e}$ 18 , bem como está presente na instituição das regiōes metropolitanas, das aglomeraçōes urbanas e das microrregiōes, do art. $25, \S 32$, e das regiōes federais administrativas geo-econômicas e sociais, do art 43, que aqui mais de cerca interessam.

Todos esses instrumentos, derivados do princípio da subsidiariedade, destinam-se a atender àquelas situaçōes intermediárias, demandantes de concentração necessária e suficiente de poder, que escapam à rigidez geométrica e positivista do federalismo clássico.

São situaçōes, todas elas, constitucionalmente previstas e voltadas a lograr a melhor atuação político-administrativa possível, que se devem desenvolver sob orientação dos referidos princípios da economicidade, da eficiência, da capacidade contributiva, da participação e da subsidiariedade.

Ora, a distribuiçẫo equânime dos custos dos serviços públicos entre os respectivos usuários, precisamente o objetivo que se busca com a instituição dessas unidades administrativas transfederativas, vem a ser a equalização tarifária, que surge, destarte, como um subprincipio do Direito Administrativo, diretamente aplicável aos serviços públicos.
Em outros termos: a equalização tarifária impõe-se como uma finalidade pública, que deve resultar da boa interpretação sistemática do artigo $25, \S 32$ (região metropolitana), combinado com o art. 37, caput, (eficiência), aos quais se acrescem, ainda em termos principiológicos, com aplicação ao regime tarifário, o art. $145, \S 1^{2}$ (que leva em conta a capacidade econômica do contribuinte) e, ainda, o art. 175, parágrafo único, III e IV (uma política tarifária que se conjugue com a obrigação manter serviço adequado), todos da Constituição.

Como facilmente se depreende, os referidos princípios constitucionais têm perfeita aplicabilidade no tratamento da complexa hipótese de prestação de serviços públicos eficientes e módicos em áreas conurbadas, pois se trata de caso em que o Direito deve servir de instrumento de realização ponderada e simultânea de todos eles, ${ }^{1}$ de modo a evitar que a fixação de tarifas de água e esgoto, nessas áreas densa e continuamente urbanizadas, subdivididas em Municípios de diferentes níveis de capacidade econômica, leve ou à inviabilização do serviço para uma parte dessa população ou à inviabilização de sua expansão ou, ainda, force a prática de tarifas altíssimas em relação à capacidade contributiva dos usuários.

O risco insuportável decorrente da desaplicação dos princípios invocados é, portanto, $a$ implantação da desigualdade injusta de tarifas e da precariedade ou, quiçá, da carência de serviços essenciais, atingindo milhares de cidadãos da Região Metropolitana de Belém.

Esse risco, que decorre da fragmentação que vem sendo pretendida pelo Município de Belém, mercê de uma interpretação positivista, literal, simplista e acanhada da Constituição, deve ser esconjurado, bastando, para tanto, o emprego da interpretação sistêmica, axiológica e teleologicamente orientada, que, embora trabalhando, igualmente, sobre os mesmos preceitos positivos, os ilumina com

1 Como bem explica ROBERT ALEXY (op. cit., p. 67), a técnica de aplicação simultânea de princípios e a ponderação, assim como a técnica de aplicaçāo simultânea de preceitos é a subsunçāo. 
os princípios pertinentes, que lhes infundem o alto sentido social e o conteúdo prático, a que devem visar.

Foi, declaradamente, para afastar riscos que possam "obstaculizar a integração e a realizaçāo das funçōes públicas de interesse comum" (sic), reconhecendo-os estarem exclusivamente submetidos à discrição do Estado Membro, que o Supremo Tribunal Federal, na Ação Direta de Inconstitucionalidade n 1841/RJ, ${ }^{1}$ decidiu, por unanimidade, seguindo voto condutor do Ministro Marco Aurélio, suspender eficácia de preceito da Constituição do Estado do Rio de Janeiro ${ }^{2}$, que admitia a ingerência de municípios na instituição de região metropolitana, aglomeração urbana ou microrregião.

Por isso é que, quaisquer decisões, administrativas ou judiciais, que possam causar ou evitar grandes riscos, não podem prescindir de segura orientação principiológica, como esta, que tão nitidamente se patenteia, no referido julgamento do Supremo Pretório. ${ }^{3}$

Afinal, o desprezo formal-positivista pelos princípios, engessa o Direito e faz, da arte e da ciência de sua aplicação, um exercício frio $e$ desvinculado de sua finalidade valiosa, como se a validade decorresse de uma mera acomodaçāo textual de continência, ensamblada por uma geometria perversa e, sobretudo, divorciada do substrato valorativo que a vivifica.

\section{A COMPETÊNCIA PARA A PRESTAÇĀO DOS SERVIÇOS PÚBLICOS DE ÁGUA E ESGOTO NAS REGIŌES METROPOLITANAS.}

Assentada a existência de uma Região Me- tropolitana, devidamente criada por lei complementar, duas situações podem se oferecer na prática:

12. Os Municípios da Região Metropolitana ainda estão executando separadamente os serviços de abastecimento ;

22. O Estado já está executando unificadamente os serviços de abastecimento.

Na primeira situação, para adequar-se à lei complementar, será necessário transferir $o$ planejamento e a execução dos serviços ao órgão integrador, que, como já se demonstrou, deve ser um órgāo estadual.

$\mathrm{Na}$ segunda situaçāo, como a lei complementar já está sendo cumprida em sua essência, pois já se está dando um tratamento homogêneo e unificado ao interesse comum, não há que se cogitar de transferências, mas, tão somente, de um aperfeiçoamento do aparelho administrativo existente.

Inexiste uma terceira alternativa, qual seria a de coexistência de um serviço de abastecimento de água e esgotamento sanitário municipal com um idêntico serviço de âmbito metropolitano.

Mas, se isso ocorresse, afrontar-se-ia a logica do sistema físico, que impōe o monopólio natural do serviço de água e esgoto, inadmitindo duplicação, embora seja possível em outros tipos de serviços públicos, como, por exemplo, no de transporte e no de comunicaçōes.

E se isso ocorresse, afrontar-se-ia também a lógica do sistema jurídico, que impōe a unidade do serviço público de água e esgoto, uma vez instituída pela competente lei complementar declaratória da existência de um interesse comum, a ser tratado unificadamente e, portanto, diferentemente dos interesses singulares municipais envolvidos.

1 Julgamento em 18 de junho de 1998, pelo Tribunal Pleno, publicado no DJ de 28 de agosto de 1998, p. 2, Ementário, Vol. 01920-01, p. 53.

2 Art. 25, § 30, Constituiçāo do Estado do Rio de Janeiro.

3 Em recente obra de nossa lavra, O Sistema Judiciário Brasileiro e a Reforma do Estado, propôs-se a introdução do instituto alemão do amicus curiae, que atuaria, a pedido dos tribunais, em casos judiciais que demandem a avaliaçāo de aspectos técnicos e metajurídicos complexos, com alternativas que possam influir na razoabilidade da decisão. (S. Paulo, Ed. Celso Bastos, 1999, p. 92). 
A eficácia juridica de uma lei complementar instituidora de região metropolitana é, precisamente, a de excepcionar a competência municipal. Assim, o que a Constituição instituiu como regra de competência ordinária municipal (art. 30, V), ela própria pode excepcionar, como regra de competência extraordinária estadual (art. 25, § 30).

Se nảo fora para produzir esse efeito integrador, forçoso é concluir-se, o instituto da região metropolitana, assim como os dois outros afins, o das aglomerações urbanas e o das microrregiões, seriam ociosos e inúteis, pois não criariam qualquer obrigação legal de que os entes políticos formadores coordenassem necessariamente suas funções.

Sem que essas funções fossem comuns e obedecessem, sob coerção jurídica, a um comando único, nāo restaria outra eficácia, no dispositivo constitucional do art. $25, \S 3^{2}$, que uma pálida indicação programática, para que as entidades conformadoras de regiões metropolitanas, aglomerações urbanas e microrregiōes cooperassem voluntariamente, se quisessem, quando quisessem e nos termos que quisessem.

Ora, não há como se vislumbrar outro motivo lógico para incluir-se essa previsão constitucional da edição de uma lei complementar estadual, que não seja para tornar mandatória a cooperação interfederativa, impondo o desejado efeito político, de deslocar a competência dos Municípios para o Estado, com vistas à prestação integrada de serviços públicos de interesse comum, que são esses que demandam tratamento técnico e econômico de escala.

Não pode ser outra, portanto, a boa exegese constitucional, senão a que atribui eficácia mandamental, excepcionadora do art. $30, \mathrm{~V}$, ao art. $25, \S 3^{\circ}$ da Constituição, pois, se outra fora, dever-se-ia aceitar que o legislador constitucional se teria satisfeito apenas com uma mera, ociosa e ineficaz indicação de uma simples possibilidade de cooperação voluntária entre Estados e seus respectivos Municípios, o que, afinal, não necessitaria de lei complementar estadual, pois não passaria de mera reiteração, em versão específica, da previsão geral de instrumentos de cooperação, encontrada, em expressāo mais ampla, no art. 241 , CF, com a redação dada pela Emenda Constitucional ne 19, de 5 de junho de 1998.

\section{UM CONTRATO QUE JAMAIS EXISTIU}

O Município de Belém, por entender, equivocadamente, que a CONSULENTE, a $C O$ SANPA, passou a ser sua "concessionária" de serviço público de água e esgoto, em razão da promulgação da Constituição de 1988 , pretende que lhe sejam aplicados dispositivos da Lei $\mathrm{n}^{2} \mathbf{8 . 9 8 7}$, de 13 de fevereiro de 1995, que dispõe sobre o regime de concessão e permis. são de prestação de serviços públicos.

Ora, já se demonstrou que a existência de uma região metropolitana desloca constitucionalmente a competência municipal, o que é o bastante para deixar sem nenhum fundamento aquela pretensão.

Contudo, ad argumentandum, ainda que não se tivesse instituído a Região Metropolitana de Belém em 1973, e, que, numa desarrazoada hipótese, felizmente meramente retórica, com o advento da Constituição de 5 de outubro de 1988, a competência para prestar o serviço de água e esgoto na Grande Belém se houvesse atomizado entre seus quatro $\mathrm{Mu}$ nicipios, e, ainda, seguindo a mesma linha de raciocínio, o Município de Belém tivesse passado a deter a competência constitucional para prestá-lo, ainda assim, desenganadamente, a relação complexa de cooperação, que é a que até então existia, não poderia se ter transformado numa relação contratual de concessāo.

Com efeito, são inconfundíveis e irredutíveis uma na outra, já que a relação de cooperação caracteriza uma complexidade de natureza tipicamente convenial, inconfundível com a relação sinalagmática contratual.

A dogmática do Direito Administrativo discrimina com nitidez os atos administrativos unilaterais dos atos administrativos bilaterais, subdivididos, estes, por sua vez, em con- 
tratos administrativos e atos administrativos complexos.'

$\mathrm{O}$ ato administrativo complexo, sob esta denominação genérica, é o que apresenta simultaneamente complexidade subjetiva e $o b$ jetiva, uma vez que se constitui pela manifestação de vontade de mais de uma entidade, cada uma delas com suas respectivas vontades autônomas, tantas quantas sejam, voltadas para produzir efeitos complexos de interesse comum.

Essa figura da Teoria Geral do Direito, que é o ato complexo, oriunda da doutrina alemã; foi desenvolvida por Otto Gierke, ao formular o conceito do Gesamtakt, aperfeiçoando-se com o posterior desenvolvimento da distinção entre contrato (Vertrag) e acordo (Vereinbarung). Deve-se, porém, aos autores italianos, sua aplicação ao Direito Administrativo, preenchendo uma lacuna teorética que não poderia ser ocupada com assimilações contrafeitas do instituto, ora ao contrato administrativo, ora ao ato administrativo unilateral, nāo obstante suas peculiaridades, que só logram cabal explicação com a admissão e a formulaçāo da teoria do ato administrativo complexo.

Realmente, enquanto no contrato, as vontades se compõem, e não se adicionam, delas resultando uma terceira espécie de vontade, que é a resultante e não a soma de ambas, no ato complexo as vontades se somam, passando a atuar, por isso, autônoma e paralelamente em prossecução dos fins comuns.

Do mesmo modo, quanto aos interesses dispostos em cada uma dessas figuras, enquanto no contrato se apresentam distintos e opostos, no ato complexo sāo sempre comuns, daí a designação, também corrente, dada a esta espécie pactual, de ato união.

$O$ doutrinador italiano Guido Zanobini, entretanto, preferiu limitar o conceito de ato complexo às relações internas da Administração, restrito às manifestaçōes de vontade concorrentes de entes ou de órgãos a ela pertencentes. Embora, ao tempo, tal redução pudes- se até fazer sentido, parece hoje injustificável sustentá-la, numa época que, ao contrário do que então sucedia, o Estado busca alijar, ao máximo, de sua máquina burocrática, tarefas que pode, com maior proveito dos administrados, delegar a particulares, ou, para melhor atendê-las, convocar a colaboração da iniciativa privada ou, ainda, simplesmente, reconhecer, em certas atividades privadas, uma eficácia administrativa, quando no atendimento de algum interesse público, que a justifique a imputaçāo.

Assim, tem-se que o ato administrativo complexo se caracteriza pelo concurso de manifestações de vontade autônomas, em que, conforme a espécie, uma delas, várias ou todas emanam da Administração Pública, tendo por objeto a constituição de uma relação jurídica de cooperaçāo ou de colaboração, visando a um resultado de interesse comum, cuja competência de atendimento caiba, pelo menos, a uma das partes acordantes.

Nas expressōes concurso de manifestações de vontade, cooperação e colaboração, aninha-se o cerne do instituto, nele se contendo a consensualidade, geradora do conteúdo obrigacional que lhe é peculiar, pois tanto a cooperação como a colaboração também exigem prestaçōes, embora não sejam recíprocas, como nos contratos.

Essas prestações podem visar a objetos distintos, o que sempre ocorre nos contratos, mas apresentam como diferença não produzirem um beneficio direto de uma parte para a outra, mas, sim, convergirem todas para uma finalidade única que é a satisfação de um interesse comum das partes acordantes.

Destacaram-se, portanto, no Direito Administrativo contemporâneo, duas modalidades de coordenação de vontades e de ação entre entes, que tornam este ato objetivamente complexo e realmente singular na fenomenologia jurídica: a cooperação e a colaboração.

Dá-se a cooperação quando as pessoas acordantes sejam, todas elas, estatais ou pa-

1 V. de nossa lavra, Curso de Direito Administrativo, Rio de Janeiro, Ed. Forense, $11^{\mathrm{a}} \mathrm{ed} ., 1996$, p. 133 e ss. 
raestatais e desempenhem atividades que hajam sido cometidas legalmente pelo menos a uma delas.

Dá-se a colaboração quando pessoas estatais valham-se de atividades desempenhadas por particulares, como preparatórias, auxiliares, substitutivas ou complementares das que lhes foram legalmente cometidas.

É, todavia, sob o critério de competência das partes, que se configuram nominadamente, em lista aberta, os atos administrativos complexos em espécie, tais como: o consórcio, o convênio, e o acordo de programa.

O consórcio se caracteriza quando todas as partes têm competência para executar o objeto comum; o convênio, quando apenas uma a possui e o acordo de programa, quando duas ou mais pessoas, sendo uma, ao menos, pessoa administrativa, coordenam o exercício harmônico de suas respectivas competências e cometimentos na execução conjunta de determinado objeto comum.

Os consórcios e convênios, não obstante o art. 116, da Lei $n^{2} 8.666$, de 21 de junho de 1993, fazer menção abrangente a convênios, acordos, ajustes e outros instrumentos congêneres, por não serem esses pactos da espécie contrato, mas da espécie acordo, obviamente não estão sujeitos às normas gerais de contratação de competência da Uniāo, aplicando-se, não obstante, como normas específicas para a Administração Federal.

Com efeito, essas regras só teriam hipotética aplicação a pactos de natureza não contratual, praticados sob a competência administrativa exclusiva de Estados, Distrito $\mathrm{Fe}$ deral e Municípios, se fosse possível admitirse uma interpretação extensiva do art. 22, XXVII, da Constituição, pretensão exegética írrita e incompatível com a sistemática da partilha de competências político-administrativas adotada.

Assim, em princípio, cada entidade da Federação pode e deve dispor sobre sua própria função administrativa, só se admitindo exce- fões constitucionais explícitas à autonomia federativa.

Os dispositivos da Lei $n^{2} 8.666$, de 21 de junho de 1993, valem, apenas, como normas gerais, de competência da Uniāo, desde que sejam de Direito Financeiro e que incidam sobre o conteúdo orçamentário-financeiro que eventualmente apresentem esses acordos, neste caso, obviamente, em razão de outra fundamentação constitucional (art. 24, I, CF).

\section{DISTINÇĀO ENTRE AS DUAS MODALIDADES CONSTITUCIONAIS DE PRESTAÇÃO DE SERVIÇOS PÚBLICOS, A DIRETA E A CONTRATUAL}

Resta esclarecer a incidência, sobre a hipótese aqui tratada, do art. 175 da Constituiçāo, que tem a seguinte redação:

“Art. 175. Incumbe ao poder público, na forma da lei, diretamente ou sob regime de concessão ou permissão, sempre através de licitação, a prestação de serviços públicos.

Parágrafo único. A lei disporá sobre:

I. o regime das empresas concessionárias e permissionárias de serviços públicos, o caráter especial de seu contrato e de sua prorrogação, bem como as condições de caducidade, fiscalização e rescisão da concessão ou permissão;

II. os direitos dos usuários;

III. política tarifária;

IV. a obrigação de manter serviço adequado." 1

Tem-se aqui, à toda evidência, uma regra constitucional excepcionadora da autonomia político-administrativa das unidades federadas (art. 18, CF), instituída especificamente para a matéria administrativa de serviços públicos, o que sempre obriga a uma interpretação restritiva, em homenagem e sempre com resguardo ao princípio federativo.

Ocorre que esse dispositivo, do art. 175, CF, já foi, ele próprio, bastante contido, no estabelecimento desta exceção. Realmente, o

1 Grifos nossos, distinguindo os dois regimes gerais de execução previstos: o direto e o contratual. 
constituinte cuidou de situar com exatidão o objeto contratual, dessa intervençāo legislativa federal excepcional (art 175, parágrafo único) sobre a prestação de serviços públicos a cargo das entidades federadas, para que não abrangesse indiscriminadamente, quaisquer outros modos e formas de prestação.

Com efeito, o seu enunciado, até mesmo reafirma o primado do princípio federativo, ao estabelecer que incumbe ao Poder Público competente prestá-lo diretamente e na forma da sua própria lei, se assim for sua opção, para, somente a seguir, tratar da modalidade de contratação com particulares, como exce. ção.

Atente-se que a expressão "diretamente", empregada no dispositivo constitucional em comento, nada tem a ver com a classificação da Administração Pública em direta e indireta, encontrada no art. 37 da Constituição. É muito comum laborar-se neste engano, por isso, Hely Lopes Meirelles, que empregava amiúde a distinção, ter advertido:

"A prestaçāo de serviço público ou de utilidade pública pode ser centralizada, descentralizada e desconcentrada, e sua execução, direta e indireta (não se confunda com Administraçāo direta e indireta)." 1

Assim, e para efeitos do art. 175, a execução da prestação do serviço público será direta, quando realizada pelo próprio Poder Competente, por seus próprios órgãos ou por seus delegatários legais ${ }^{2}$, neles incluindo-se as entidades paraestatais.

A execução será indireta quando realizada por terceiros nas condiçōes regulamentares, destacando-se as modalidades unilaterais, todas precárias e as modalidades bilaterais, de natureza contratual.

À luz dessa distinção, é que se deve interpretar o art 175, CF. Nele se contém dois diferentes comandos e prevê a edição de duas leis distintas.
O primeiro comando é o mais geral: determina que o poder público, em qualquer caso, atuando diretamente ou por contrato, deverá sempre prestar serviços públicos regrados, ou seja, na forma da lei, ficando claro que esta primeira lei mencionada, no caput do artigo, poderá ser, conforme o caso, federal, estadual, distrital federal ou municipal, pois será sempre aquela editada pela entidade política constitucionalmente competente para instituir e regrar com exclusividade o próprio serviço.

O segundo comando, é mais restrito e de natureza alternativa: se o poder público competente não optar por executar diretamente o serviço público, por seus órgãos ou entidades administrativos e exclusivamente sob suas próprias regras, e preferir executá-lo indiretamente, contratando-a com executores privados. Neste caso só poderá fazê-lo através dos contratos nominados de concessão e de permissão, submetendo-se, nesta hipótese, a um duplo regramento federal de exceçāo, ou seja, primeiro, às já referidas normas específicas próprias sobre o regime de concessões e permissões (que é a lei prevista no art. 175, parágrafo único, CF) e, segundo, às normas gerais federais sobre licitaçōes e contrataçōes (que são as normas gerais previstas no art. 22, XXVII, CF).

Em síntese: a exceção instituída à normalidade do regime federativo autônomo das unidades da Federação se circunscreve apenas ao tratamento das duas formas admitidas de delegação contratual de execução de serviços públicos, a concessão e a permissão, que ficaram, portanto, duplamente submetidas a leis federais: as normas gerais nacionais de licitação e de contratação e as normas específicas nacionais para esses dois regimes de execução contratuait.

São essas duas normatividades nacionais referidas que devem ser estabelecidas por lei

1 HELY LOPES MEIRELLES, Direito Administrativo Brasileiro, S.Paulo, Malheiros Editores, 1998, $23^{a}$ ediçāo, p.295 (destaque nosso em itálico).

2 HELY LOPES MEIRELLES prefere dizê-lo: "Considera-se serviço em execução direta sempre que o encarregado de seu oferecimento ao público o realiza pessoalmente, ou por seus órgãos, ou por seus prepostos (não por terceiros contratantes)", id. ibid., p. 296 (grifos nossos). 
federal, sendo que a segunda mençāo feita a lei, que é aquela que se encontra no parágrafo único do art. 175, ainda assim, a limita a regrar apenas os quatro temas itemizados no próprio parágrafo: o regime contratual especial, os direitos dos usuários, a política tarifária e a obrigação de manter serviço adequado (parágrafo único, incisos I, II, III e IV).

Disso decorre que, inexistindo contrato de concessão ou de permissão com particulares, o serviço público e seu modo de excução reger-se-ão integralmente pela lei da entidade política competente, sem qualquer interferência federal.

Ora, essa lei federal, que veio reger os contratos de concessão e de permissão de serviços públicos, prevista no parágrafo único do art. 175 da Constituição, é a Lei $n^{\circ} 8.897$, de 13 de fevereiro de 1995, que, em sua epígrafe, declara ser este, sem dúvida, e não mais que este, o seu restrito escopo: o de dispor "sobre o regime de concessão e permissão de prestação de serviços públicos".

Trata-se, insista-se ainda mais uma vez, pois esta é a exegética que se impõe sob o princípio federativo, de uma lei aplicável aos Estados, Distrito Federal e Municipios, tãosomente na ocorrência das duas hipóteses contratuais nela previstas, ou seja, se apenas uma das duas vier a ser, entre tantas opçōes que tem à sua disposição a unidade federada competente para executar um serviço público, a solução escolhida.

Ora, essa lei federal, não obstante a clara distinção entre os dois regimes básicos para a execução da prestação dos serviços públi$\cos$, o de execução direta, apenas por meio de relações administrativas, e o da execução indireta, por particulares, caracterizada pelas relações contratais, e, de ser aplicada apenas na ocorrência dos dois únicos casos contratuais, de concessões e de permissões, ainda assim vem de ser equivocadamente invocada pelo Município de Belém, como se fora a lei regedora das relações entre ele a $C O N S U$ LENTE, e como esta fosse uma concessionária ou permissionária contratual da execução de serviços públicos de água e esgoto.

Desde logo, jamais existiram relaçōes jurí- dicas diretas de execução entre ambas, pois quem se relaciona com o Município de Belém é o Estado do Pará, unidade federada a que pertence.

Mas mesmo o Estado do Pará, ele próprio, jamais se relacionou contratualmente com o Município de Belém.

É evidente que o Município de Belém equivocou-se duplamente, ao dirigir-se extrajudicialmente e judicialmente à CONSULENTE: a uma, ao afirmar a existência de alguma relação de execução de prestaçāo de serviço público de saneamento entre ambos; e, a duas, ainda que essa assertiva fosse verdadeira, ao insistir na natureza contratual dessa hipotética relação, como se existisse algum contrato que tivesse sido, em algum tempo, entre ambos celebrado.

Esboroa-se, a esta altura, toda a precária argumentação da Municipalidade de Belém; confira-se:

Primeiro: porque jamais existiu qualquer relação direta de execução de prestação de serviços de água e esgoto entre o Município de Belém e a CONSULENTE.

Segundo: porque com maior razão, jamais existiu, em qualquer tempo, um contrato de concessāo, que tivesse sido outorgado à CONSULENTE pelo Município de Belém.

Terceiro: porque a antiga relação existente, que existia desde longa data, entre o Estado do Pará e o seu Município da Capital, foi uma relação administrativa de cooperação facultativa, que veio a ser transformada na atual relação constitucional-administrativa de cooperação necessária, com a criação da Região Metropolitana de Belém;

Quarto: porque a União não tem competência para regrar relações de cooperação entre Estado e seus Municípios, nem as facultativas (anteriores a 1973), previstas no art. 241, CF, nem as necessárias (posteriores a 1973), previstas no art $25, \S .3^{\circ}, \mathrm{CF}$.

Quinto: porque a competência constitucional excepcional da União para legislar sobre serviços públicos dos Estados, Distrito Federal e Municípios, está estritamente limitada, às duas formas contratuais nominadas expressamente contempladas na Constituição: $a$ 
concessão e a permissāo, outorgadas a particulares (art. 175, CF);

Sexto: porque as normas gerais de contratação, de competência da União, tampouco podem alcançar relaçōes jurídicas não contratuais de cooperação que são travadas entre entes da Federação. Novamente e por clareza: tanto faz serem as cooperações facultativas, previstas, que estão, destacadamente, em dispositivo constitucional, que atribui, sem qualquer excepcionalidade, os cabíveis regramentos, às suas respectivas legislaçōes (art. 241, CF), como as cooperaçōes necessárias, também caracterizadas constitucionalmente, mas com seu regramento a cargo exclusivo dos Estados-membros (art. 25, §32, CF).

Sétimo: porque, mesmo que, por hipótese, fosse possível aplicar por analogia (e, assim, ao arrepio do art. 241 da Constituiçāo) as normas gerais federais de contrataçāo, a relaçōes jurídicas de cooperação, sejam elas facultativas (art 241, CF) ou necessárias (art $25, \S 3^{2}, \mathrm{CF}$ ), celebradas entre entes federados, isso em nada mais poderia alterar o deslocamento de competência efetivamente ocorrido na Região Metropolitana de Belém, por força da Lei Complementar $n^{2} 14$, de 8 de junho de 1998, mormente depois de sua posterior ratificação, advinda com a promulgação da Lei Complementar do Estado do Pará, n² 27, de 19 de outubro de 1995, que está em pleno e indisputado vigor, bem como todos os atos delas decorrentes.

Oitavo: porque mesmo que atos de cooperação entre Estado e Municípios tivessem sido praticados sob o nomen juris equivocado de "concessões" ou de "permissões", independentemente antes ou depois da entrada em vigor da Constituição de 1988 , ou da Lei $n^{2}$ 8.987 , de 13 de fevereiro de 1995 , é elementar que uma errônea denominação não tem qualquer eficácia para " transformá-los em contrato" e, muito menos, para reduzir a autonomia constitucional do ente federado e submetê-lo, assim, a uma lei federal regedora de contrataçōes.

Portanto, de um lado, a CONSULENTE não tem e jamais teve qualquer vínculo com o Município de Belém, e, de outro, o Estado tampouco se quadra como concessionário ou permissionário de serviços públicos Municipais (ou vice-versa), pois as relaçōes jurídicas que se estabelecem entre essas entidades políticas (a que podem se acrescer as suas respectivas delegatárias), não são relações contratuais, mas relações de colaboração, tanto as negociadas como as impostas pela lei estadual, pouco importa, mas sem jamais ceder a normas excepcionadoras da autonomia político-administrativa desses entes, uma vez que o rationale de terem sido instituídas é, única e exclusivamente, reger as duas únicas hipóteses de contratação de execução de serviços públicos com entidades privadas.

Em suma: essas relações interadministrativas de cooperação, como ficou acima demonstrado a partir de suas duas expressas previsōes constitucionais, a facultativa e a necessária (respectivamente arts. 241 e 25 , § 30, CF), não se submetem a norma federal ordinária de nenhuma espécie, sendo impertinente a invocação da Lei Federal $\mathbf{n}^{0} \mathbf{8 . 9 8 7}$, de 13 de fevereiro de 1995 , e descabida a aplicaçāo pretendida do seu art. $42, \S 2^{\circ}$, que trata de relaçōes contratuais de "concessōes em caráter precário", ou "com prazo vencido" ou "em vigor com prazo indeterminado".

\section{CONCLUSÕES E RESPOSTAS AOS QUESITOS}

À vista do exposto, está-se em condições de, fundamentadamente, passar a responder à quesitaçāo da CONSULENTE.

\section{QUESITO}

"Sob o prisma da Constituição e da legislação infraconstitucional aplicável á matéria, seria correto afirmar que nos serviços públicos de abastecimento de água e coleta de esgotos prestados nos Municípios que compõem a Região Metropolitana de Belém (criada por forfa de Lei Complementar do Esta. do), predomina o interesse metropolitano em detrimento do interesse local?"

\section{RESPOSTA}

A resposta é afirmativa. 
O interesse local, que é a regra federativa, por expressa previsão constitucional, cede ao interesse comum, que, por isso, recai sob a normatividade exclusiva do Estado-membro, que se torna, assim, o Poder Público competente "para integrar a organização, o planejamento e a execução de funções públicas de interesse comum" (art. 25, $\S 3^{\circ}, \mathrm{CF}$ ).

\section{QUESITO}

"A integração dos sistemas de abastecimento de água que servem aos municípios da Região Metropolitana de Belém, seria fator essencial para determinar a prevalência do interesse metropolitano em face do interesse local?"

\section{RESPOSTA}

A resposta é parcialmente afirmativa, no seguinte sentido.

O serviço público de saneamento de uma região metropolitana é uma unidade jurídica ex vi legis, tratada como uma universitas rerum, especificamente afeta à satisfação do interesse comum que vem declarado na Lei Complementar instituidora.

Por isso, uma vez legislada a opção pela prestaçāo desse serviço de modo unitário e uniforme, ela se fará por força de lei, independentemente de quaisquer outras considerações de fato, que favoreçam ou não aquela escolha legal, como, no caso em questāo, efetivamente favorece de facto a existência da integração física dos sistemas de abastecimento de água.

Está claro, porém, que, uma vez já existente essa integração física do serviço de água $e$ esgoto na Região Metropolitana de Belém, satisfatória da finalidade pública estabelecida pelo legislador constitucional, e instituída juridicamente pelo legislador complementar estadual, ela não poderá mais ser rompida por decisão unilateral, nem de qualquer dos seus Municípios formadores, nem mesmo por lei municipal, nem pela própria Administração estadual, nem mesmo pela lei ordinária estadual.
Em suma, em resposta, a integração física dos sistemas de abastecimento existente não é um fator essencial para determinar a prevalência do interesse metropolitano em face do interesse local, mas o é para garantir que se não a perturbe enquanto a Lei Complementar competente assim o prescrever.

\section{QUESITO}

"Predominando o interesse metropolitano, descaracterizado o interesse local, seria correto afirmar-se que a titularidade do Poder de Concessão seria do Estado (pessoa jurídica de direito público interno), mesmo existindo contrato de concessão firmado com alguns municípios da $R M B$, antes da promulgação da Constituição Federal de 1988, da Lei de Concessōes, e da Lei Complementar que criou a RMB?"

\section{RESPOSTA}

A resposta é afirmativa, com as observaçōes que se seguem.

É correta a asserção de que, em qualquer das três alternativas operacionais abertas pelo art. $5^{\mathfrak{Q}}$, parágrafo único, da Lei Complementar do Estado do Pará n² 27, de 19 de outubro de 1995 , em que se prevê ou a execução pela outorga ${ }^{1}$ do serviço à entidade estadual, ou a execução por empresa de âmbito metropolitano, criada para esse fim, ou a execução do serviço mediante outros processos que venham a ser estabelecidos por convênio entre todos os entes interessados, todas essas entidades executoras, quaisquer que sejam, serão sempre delegatárias, e o Estado, será sempre o prestador delegante, variando a titulação jurídica das delegação.

Assim é que essa delegação poderá ter uma de duas titulaçōes jurídicas: ou será uma delegação legal, ou seja, a transferência de execução decorrerá imediatamente da própria lei estadual que instituir entidades executoras, como é o caso da própria CONSULENTE, que, por isso, já satisfaz um dos critérios admitidos pela Lei Complementar, ou, alternativamente, poderá ser uma delegação conces-

1 NB: Ainda mais uma vez equivocadamente denominada "concessão". 
sional, ou seja, a transferência de execução dos serviços se operará por contrato de concessão, sujeito, por isso, e apenas neste caso, à Lei Federal n 8.987 , de 13 de fevereiro de 1995.

Existe, portanto, esta e única hipótese, prevista na Lei Complementar, em que ficou admitida uma solução concessional para a execução dos serviços de água e esgoto na Região Metropolitana de Belém, sendo, por esta simples razāo, a única em que o Estado figuraria no contrato, se e quando vier a ser adotada, como "Poder Concedente".

Finalmente, quanto aos demais impropriamente chamados "contratos de concessâo", que hajam sido firmados entre o Estado do Pará e qualquer dos seus Municípios formadores da Região Metropolitana de Belém, deve-se verificar se são anteriores ou posteriores a 8 de junho de 1973, quando foi instituída a Região Metropolitana de Belém.

Se são documentos anteriores àquela data, são pactos de cooperação conveniais, de cooperação facultativa, que perderam vigência com a mudança das relaçōes de cooperação de facultativa para necessária, ocorrida com a superveniência da criação da Regiāo Metropolitana de Belém

Se são posteriores à criação da Região Metropolitana de Belém, já não podem mais ser considerados sequer como pactos de cooperação, já que a relação deixou de ser convencional e passou a ser legal, nāo possuindo mais qualquer outra eficácia, tais documentos, que a de uma simples declaração conjunta de intenções, uma vez que as normas a serem obedecidas na relação entre Estado e Municípios da Região, são apenas aquelas estabelecidas pela legislação metropolitana estadual aplicável.

\section{QUESITO}

"O fato de existir contrato de concessão com alguns municipios da RMB, firmados antes da promulgação da Constituição Federal de 1988, da lei de Concessões e da Lei Complementar que criou a RMB, seria fato impeditivo capaz de invalidar a tese de que nas Regiōes Metropolitanas criadas regularmente por Lei Complementar, o Poder Concedente seria o Estado, por predominar, no caso, $o$ interesse metropolitano?"

\section{RESPOSTA}

A resposta é negativa.

Conforme se expôs na Resposta do Quesito anterior, não se deve ater literalmente ao errôneo enquadramento conferido nos próprios documentos formalizadores de relação de cooperação convenial estabelecidos entre entes administrativos.

Com efeito, conforme exposto, o Estado não "contrata" com Município, nem viceversa, a execução de serviços que devam satisfazer interesses públicos postos sob a cura de ambos (como é o caso do art. 23, II, VI e, principalmente, $\mathrm{XI}, \mathrm{CF}$, na referência a saneamento básico).

Uma alegação de que o apego ao nomen juris, prevaleceria sobre a lógica e a boa doutrina seria descabida. Recorde-se a lição, sempre nova, do nosso grande mestre da hermenêutica Carlos Maximiliano:

“As próprias definiçōes oferecidas pelo legislador não guiam só por si. Pode haver palavras acrescentadas às expressões que ele definiu, ou quaisquer outras circunstâncias que induzam a crer não se tratar precisa e exclusivamente daquilo cujo sentido ele procurou expor." 1

A existência de relaçōes de cooperação facultativas, de natureza espontânea, travadas entre o Estado do Pará e outros Municípios, não se confunde com instituição de uma integração de natureza obrigatória nos casos previstos no art. $25, \S 3^{\circ}$, da Constituição.

São duas situaçōes distintas:

Na primeira, Estado e Município integramse voluntariamente para lograr resultados de

1 CARLOS MAXILIANO, Hermenêutica e Aplicaçāo do Direito, Rio de Janeiro, Ed. Forense, 1995, $15^{\mathbf{2}}$ edição, p. 119, seguindo-se a seguinte advertência aos exegetas literais: "Nada de exclusivo apego aos vocábulos.". 
interesse público comum, que, no caso de serviços de água e esgoto, estāo postos por cláusula geral, sob a competência executora específica do Município (art. 30, V, CF).

Na segunda, Estado e Municípios integramse obrigatoriamente para lograr resultados também de interesse público comum mas que, diferentemente, foram postos, por cláusula constitucional de exceção, sob a competência executora estadual (art. $25, \S 3^{2}, \mathrm{CF}$ ).

A integração voluntária para execução do serviço de águas e esgoto na Grande Belém, existiu até mesmo por motivos de fato, decorrentes da debilidade dos Municípios para provê-los, até o advento da Lei Complementar Federal no 14, de 8 de junho de 1973. Assim, até então, existiam relaçōes jurídicas de cooperaçāo pactuadas entre Estado $\mathrm{e}$ Município.

A partir daquela data, ratificando-se em 1995, sob a Constituição vigente, $a$ integração no âmbito da Regiāo Metropolitana de Belém passou a ser necessária, submetida às regras estaduais estabelecidas, o que transformou, em todos os quatro Municípios que a conformam, inclusive o de Belém, a relação de cooperação facultativa convenial em relação de cooperação necessária legal, submetida às regras estaduais.

\section{$5^{\circ}$ QUESITO}

“Na remota hipótese de prevalecer a tese de que predominaria o interesse local em detrimento do interesse metropolitano na RMB, para os serviços de abastecimento de água e coleta de esgotos na região prestados, seria correto afirmar que, nas concessões de fato, portanto a título precário, o prazo previsto no parágrafo 22 , do artigo 42 , da Lei 8.987/95, - necessário à realização dos levantamentos e avaliaçōes indispensáveis à organização das licitações que precederão a outorga das concessões que as substituirão, prazo esse que não poderá ser inferior a 24 (vinte e quatro) meses - conta-se a partir da iniciativa do Poder Concedente para esse determinado fim ou da promulgação da referida Lei?"

\section{RESPOSTA}

$O$ quesito fica parcialmente prejudicado pelas respostas oferecidas aos anteriores.

Duas são as suposiçōes insustentáveis no Quesito: 12. que o interesse local prevalece sobre o interesse metropolitano e $2^{2}$. que se aplicam às relações de cooperação entre unidades federadas, igualmente competentes para o saneamento básico, as regras federais de exceção à autonomia político-administrativa dessas entidades, que são, como se expôs, baixadas, estritamente, para serem aplicadas no caso de contratação concessional com particulares.

Destarte, se a relação era voluntária, como ocorria numa hipótese de integração pactuada, para desfazê -la caberia a simples denúncia, e, neste caso, se outro prazo não tivesse sido convencionado, ela seria executada no tempo necessário - que poderia ser o convencionado, o arbitrado ou o judicialmente fixado - para concluir os levantamentos e avaliaçōes indispensáveis, que deveriam discriminar os bens públicos envolvidos e capacitar a entidade competente, que retomaria a execução do serviço, a continuar a prestá-lo sem solução de continuidade.

Mas, se a relação de cooperação é obrigatória, como ocorre na integração constitucional necessária, instituída nas regiões metropolitanas, aglomeraçōes urbanas e microrregiões, não há possibilidade de desfazimento administrativo. Somente nova lei complementar poderá extingui-la, dispondo, neste caso, imediatamente, sobre a devolução dos serviços aos municípios, ou delegando ao Executivo estadual fazê-lo mediatamente.

A aludida "remota hipótese" da indagaçāo contida no Quesito, de "concessão de fato, portanto a título precário", como suposto da aplicaçāo do art. $42, \S 2^{2}$, da Lei Federal no 8.987, de 13 de fevereiro de 1995 , não faz qualquer sentido no âmbito de uma Região Metropolitana.

Apenas fora das Regiões Metropolitanas ou das demais formas agregativas de cooperação necessária, um Município poderá optar, indiferentemente, pela execução da prestação por seus próprios órgãos ou por entes de sua criação, por entes de cooperação voluntária ou 
por contratados, concessionários ou permissionários particulares. ${ }^{1}$

De resto, basta a leitura atenta do referido art. $42, \S 2^{2}$, da Lei Federal $n^{2} 8.987$, de 13 de fevereiro de 1995, para verificar-se que este dispositivo contém normas excepcionais aplicáveis apenas às três situações atípicas de relações contratuais concessionais, que identifica perfeitamente, e, ainda, o que é igualmente relevante, essa aplicação caberá apenas na hipótese de vir a ser realizada uma nova concessão ("...que precederão à outorga das concessões que as substituirão”).

Portanto, se o Poder Público competente de um Município, sempre entendido, fora de uma Região Metropolitana, que mantenha um contrato de concessão nas condições especificadas no art. 42, \$20, da Lei 8.987, de 13 de fevereiro de 1995, não se dispuser a substituir o concessionário, e pretender, ao revés, executar diretamente o serviço, uma discrição que lhe é aberta pela própria Constituição (art. 175, caput), tampouco terá qualquer aplicaçāo aquele prazo específico, que se contará, ademais, para que faça sentido a sua previsão legal, a partir da notificação do Poder Concedente às entidades privadas, suas concessionárias, da intenção de "outorgar concessāo que as substituirāo". ${ }^{2}$

\section{$6^{0}$ QUESITO}

"Na eventualidade de configurar-se a hipótese do parágrafo $2 o$, do artigo 42 , da Lei $8.987 / 95$, qual o procedimento que deveria ser observado pelo Poder Concedente e quais as providencias judiciais e extrajudiciais que a concessionária deveria adotar na defesa de seus interesses?"

\section{RESPOSTA}

A hipótese é, realmente, inconfigurável.

A pretensão do Município de Belém na aplicaçāo do art. 42, $\S 2^{2}$, da Lei federal $n^{\ell}$ 8.987, de 13 de fevereiro de 1995, com o objetivo de compelir a CONSULENTE, com a qual não tem nem pode provar ter tido qualquer relação jurídica bilateral de transferência de execução de serviços públicos, a submeter-se a um processo prescrito exclusivamente para a extinçāo de "concessão", e, ainda mais, para que uma outra seja licitada em seu lugar, não tem qualquer sentido jurídico adequado no ordenamento jurídico brasileiro:

Primo: porque o Município de Belém não é titular da competência para executá-los (art. $25, \S 3^{2}, C F$ ), uma vez que se encontra instituída uma Regiāo Metropolitana, vigente desde 8 de junho de 1973 .

Secundo: porque, mesmo que o Município de Belém ainda fosse hoje o titular da competência, caso a Lei Complementar $n^{2} 27$ de 19 de outubro de 1995 não estivesse vigente e mantido a Região Metropolitana instituída pela Lei Federal $n^{2} 14$, de 8 de junho de 1973 . a CONSULENTE nem mesmo assim seria sua concessionária, pois jamais firmou contrato com o Município de Belém para executá-los, mas, ao contrário, sempre os executou ex-vi legis, como delegatária legal do Estado do Pará, que, por sua vez, os prestava, até 1973, em regime administrativo de colaboração

1 NB - Nada impede, porém, que uma entidade paraestatal, de qualquer dos Entes Federados, licite, atuando como um particular, a contratação de um serviço público de outra entidade política, desde que o permitam os seus respectivos estatutos. Se a paraestatal vier a ser a vencedora, neste caso, sim, ter-se-ia estabelecido um contrato entre ela um Poder Concedente. Também, apenas nesta hipótese, a relação jurídica da licitação e da contratação estariam submetidas à referida Lei federal $n^{\circ}$ 8.987/95.

2 NB - Outra fora a interpretação, ao se a contar o prazo de 24 meses apenas a partir da publicação da Lei 8.987/95, o legislador estaria limitando no tempo uma faculdade político-administrativa, inerente às entidades da Federação, de decidirem, como melhor lhes conviesse, a modalidade de prestação de um serviço público de sua competência. Parece claro, por isso, que esse prazo só se há e se contar a partir dessa decisão político-administrativa autônoma, quando venha a ser tomada, pelo Poder Concedente, de substituir uma concessão por outra, e apenas nesta hipótese, pois, em qualquer outra, colidiria com o princípio federativo, interferindo na competência constitucional daquelas entidades. 
graciosa e voluntária a esse Município e, posteriormente, ' passou a prestá-los como executora necessúria de serviços públicos integrados da sua Região Metropolitana.

Tertio: porque, não existindo nem podendo existir qualquer concessão, uma vez que a CONSULENTE não é um particular contratado, mas uma entidade paraestatal executora, nesta qualidade, de cometimentos estaduais, não tem qualquer aplicação a Lei federal $\mathrm{n}^{2} 8.987$, de 13 de fevereiro de 1995 , e em conseqüiencia, seu art. $42, \S 2^{2}$.

Prosseguindo a resposta ao Quesito, agora com vistas à defesa dos interesses da $\mathrm{CON}$ SULENTE, aconselha-se, não só em defesa de seu patrimônio paraestatal como, e principalmente, em salvaguarda da continuidade e regularidade institucional do serviço prestado, e, epecialmente, para evitar graves prejuízos ao saneamento público da Região e a seus usuários, que desse procedimento possa decorrer em comprometimento de toda a área metropolitana, a que serve por cometimento legal, a valer-se de interdito para a garantia da posse ameaçada de turbação ilegal, cabendo, por outro lado, ao Estado do Pará, em ação própria, sustentar sua competência, como ente executor constitucional dos serviços de água e esgoto integrados para a Regiāo Metropolitana de Belém, bem como a validade da opção feita, até o momento prevalecente, de manter-se o serviço a cargo da entidade paraestatal estadual que já a vem desempenhando, a CONSULENTE.

$\mathrm{Na}$ medida cautelar ajuizada pelo Município de Belém, a CONSULENTE é parte ilegítima, uma vez que, no âmbito da Regiões Metropolitanas, as relações constitucionais e administrativas se travam entre pessoas jurídicas políticas.

Essas cautelas, por óbvio, em nada prejudicam, muito ao contrário, robustecem a necessária e importante providência político-administrativa, que cabe ao Estado do Pará, de levar a controvérsia ao Conselho Metropolitano, instituído pela Lei Complementar $n^{2} 27$, de 19 de outubro de 1995, do Estado do Pará.
A convocação do Conselho Metropolitano, entre outros temas de pauta, que deverão levar adiante a defesa institucional da Região, pode incluir uma comunicação formal, aos demais Municípios participantes, dos riscos que comprometem a integração constitucional dos serviços de saneamento de toda a área Metropolitana, ante a postulação administrativa e judicial solitária do Município de Belém, tais como sejam, a curto e médio prazo, com maior probabilidade, a perturbação do serviço, o aumento de tarifas para os usuários, o desabastecimento, a que ficariam sujeitos os demais Municípios da Região, e às imensas dificuldades de expansão e melhoria dos serviços, na hipótese de inércia na defesa de seus legítimos interesses em assegurar, ainda que valendo-se também de meios judiciais, $a$ intangibilidade jurídica da integração constitucional dos serviços de saneamento que os beneficia.

Poderá, ainda, aquele Conselho, conforme seu juízo de conveniência e de oportunidade, no uso de suas atribuiçōes exclusivas, confirmar ou alterar os modos de execução da prestação dos serviços de saneamento previstos no art $5^{\circ}$, parágrafo único, da Lei Complementar $n^{2} 27$, de 19 de outubro de 1995, e, igualmente, se posicionar também ante esse sério risco a que podem ficar sujeitos os demais Municípios integrados e, afinal, ante o próprio destino institucional da Região Metropolitana de Belém.

Estão esgotados os Quesitos formulados pela CONSULENTE.

Está-se concluindo este Parecer.

Não se o fará, porém, sem que se deixe manifestada uma perplexidade, suscitada pelo fato de retornar-se ainda, nesta oportunidade, da virada de século e de milênio, em que certas premissas já pareciam ter sido superadas, em benefício do interesse público a cargo dos Governos, ao reenfrentamento, uma vez mais, de uma cega resistência, ilógica e anacrônica, às soluções de economia de escala.

Essas obviedades, que, por vezes, levam tantos séculos para que as percebamos, uma 
vez iluminadas, deveriam se impor tão-somente pelos fatos e pelo bom senso, sem necessidade de coação jurídica.

E tudo não seria nada mais que a manifestação dessa mera perplexidade, se não fora, como conseqüência, a preocupação, que fica, quanto à danosa repercussão, que, possivelmente, essa esdrúxula atitude poderá desencadear sobre a sorte do abastecimento de água, justamente das populações mais carentes da Região Metropolitana de Belém.

Estas reflexōes vêm aqui acrescentadas, pois, afinal, a própria existência de Estados e de Governos, não importa quantos sejam, como estejam dispostos e sob que combinações de competência se encontrem organizados, pressupõe que, logicamente, devam atuar harmonicamente na prossecução dos interesses públicos que lhe estão afetos, e não um contra os outros, pois essa disputa é, em si mesma, além de irracional, um desvio de finalidade.

Que valha, como fio condutor da interpretação adotada neste Parecer, que se pretende, sobretudo, construtiva em benefício dos cidadãos da Grande Belém, a quase sesquicentenária advertência de John Ruskin, lembrada na epígrafe deste trabalho.

"Governo e cooperação são, em tudo, as leis do progresso; anarquia e antagonismo, as leis do retrocesso". 1

Este é o Parecer,

Salvo melhor juízo.

Rio de Janeiro, 14 de janeiro de 2000.

DIOGO DE FIGUEIREDO MOREIRA NETO

Advogado, inscrição $n^{2} 8.275$ OAB/RJ 